$$
\text { UNIVERSIDADE DE SÃO PAULO }
$$

FACULDADE DE ZOOTECNIA E ENGENHARIA DE ALIMENTOS

\title{
FERNANDA BOVO
}

\section{Avaliação da eficiência de bactérias ácido-láticas para descontaminação de aflatoxina $M_{1}$}




\section{FERNANDA BOVO}

\section{Avaliação da eficiência de bactérias ácido-láticas para descontaminação de aflatoxina $M_{1}$}

Dissertação apresentada à Faculdade de Zootecnia e Engenharia de Alimentos da Universidade de São Paulo, como parte dos requisitos para a obtenção do título de Mestre em Engenharia de Alimentos.

Área de Concentração: Ciências da Engenharia de Alimentos

Orientador: Prof. Dr. Carlos Augusto Fernandes de Oliveira 
Aos meus pais, Luiz Renato e Maria Antonia, por todo o apoio, incentivo e amor dados durante todos os anos de minha vida. 


\section{AGRADECIMENTOS}

Ao Prof. Dr. Carlos Augusto Fernandes de Oliveira pela orientação, pelos ensinamentos, e por toda a contribuição para o meu crescimento científico, intelectual e pessoal.

À minha família, por todo o apoio e por todos os momentos de felicidade durante a minha vida inteira.

Ao meu noivo Francis, por todo o amor, carinho e paciência dedicados a mim durante todos esses anos.

A todos os meus amigos, que sempre souberam me incentivar a continuar meus estudos e construir uma vida acadêmica.

À Roice, técnica do laboratório, por toda a ajuda com as análises cromatográficas e pelos anos de amizade.

À Estela, pela ajuda desprendida durante o projeto, principalmente com as análises estatísticas, e também por nossa amizade.

Ao Carlos Corassin, obrigada pela colaboração em todos os trabalhos e por nossa amizade.

À Carolina, por me ajudar a compreender melhor o funcionamento das bactérias.

Às estagiárias Monique e Thaiane, por toda a ajuda durante a execução do projeto.

À Riana, obrigada pela amizade, por toda a ajuda e por sua companhia nas viagens diárias até Pirassununga. 
À Cristina, Eliane, Graziela, Rafaella e Renata, pela amizade e por todo o tempo que passamos juntas durante esse período.

À Izildinha Moreno do TECNOLAT - Centro de Pesquisa e Desenvolvimento de Laticínios do Instituto de Tecnologia de Alimentos (ITAL) de Campinas/SP, e à Danisco do Brasil Ltda., pela doação das cepas bacterianas para a realização desse projeto.

À Faculdade de Zootecnia e Engenharia de Alimentos, pela disponibilização do espaço para a realização do projeto e por todo suprimento necessário.

À CAPES, pelo suporte financeiro providenciado durante todo o período do mestrado. 
"Todo grande progresso da ciência resultou de uma nova audácia da imaginação." 


\section{RESUMO}

BOVO, F. Avaliação da eficiência de bactérias ácido-láticas para descontaminação de aflatoxina $\mathbf{M}_{1}$. 2011. 69f. Dissertação (Mestrado) - Faculdade de Zootecnia e Engenharia de Alimentos, Universidade de São Paulo, Pirassununga, 2011.

O objetivo do trabalho foi avaliar a capacidade de cepas de bactérias ácido-láticas (BAL) em remover a aflatoxina $M_{1}\left(A F M_{1}\right)$ em solução tampão fosfato salina (TFS) e em amostras de leite. Nos ensaios com TFS, verificou-se a influência do tempo de contato (15 min. ou 24 horas) entre as células de sete cepas de BAL e AFM 1 , as diferenças entre a eficiência de remoção das bactérias viáveis e inviabilizadas termicamente, e a estabilidade do complexo BAL/AFM 1 formado. As três cepas de BAL com maior percentual (> 33\%) de remoção da $\mathrm{AFM}_{1}$ nos ensaios com TFS foram re-avaliadas utilizando-se leite UHT (ultra-high-temperature) desnatado artificialmente contaminado com $\mathrm{AFM}_{1}$. Para isso, foram utilizadas somente células inviabilizadas termicamente, verificando-se o efeito da temperatura $\left(4^{\circ} \mathrm{C}\right.$ ou $\left.37^{\circ} \mathrm{C}\right)$ sobre a capacidade de remoção da toxina por 15 minutos. A remoção média da $A F M_{1}$ pelas cepas de BAL em TFS variou entre $5,60 \pm 0,45$ e $45,67 \pm 1,65 \%$ ( $\left.n=3\right)$, sendo que as células inviáveis obtiveram percentuais de remoção de $\mathrm{AFM}_{1}$ significativamente maiores que as células viáveis, em ambos os tempos de contato analisados (15 min. ou 24 horas), não havendo diferença significativa entre os tempos. Observou-se que o complexo BAL/AFM 1 obtido nos ensaios com TFS é instável, pois $40,57 \pm 4,66$ a $87,37 \pm 1,82 \%$ da $\mathrm{AFM}_{1}$ retida pela bactéria foram recuperados em solução após a lavagem do complexo com TFS. As três cepas de BAL com maior percentual de remoção da $\mathrm{AFM}_{1}$ em TFS (Lactobacillus rhamnosus, Lactobacillus delbrueckii spp. bulgaricus e Bifidobacterium lactis) não apresentaram diferenças significativas nos ensaios com leite UHT a $37^{\circ} \mathrm{C}$. Somente $B$. lactis apresentou maior capacidade de remover a $A F M_{1}$ do leite $U H T$ a $4^{\circ} \mathrm{C}$. Os resultados demonstraram que a remoção de $\mathrm{AFM}_{1}$ empregando-se as BAL em alimentos é viável para reduzir as concentrações da toxina a níveis seguros. Entretanto, estudos adicionais são necessários a fim de investigar os mecanismos envolvidos na remoção da toxina pelas BAL com vistas à aplicação em indústrias de alimentos. 
Palavras-chave: Aflatoxina $M_{1}$, Bactérias ácido-láticas, Descontaminação, Leite 


\begin{abstract}
BOVO, F. Evaluation of the efficiency of lactic acid bacteria for the decontamination of aflatoxin $\mathbf{M}_{1} \cdot$ 2011. 69p. M. Sc. Dissertation - Faculdade de Zootecnia e Engenharia de Alimentos, Universidade de São Paulo, Pirassununga, 2011.
\end{abstract}

The purpose of this study was to evaluate the ability of strains of lactic acid bacteria $(L A B)$ to remove aflatoxin $M_{1}\left(A F M_{1}\right)$ in phosphate buffer saline (PBS) and in milk samples. In the assays with PBS, the influence of contact time (15 min. or 24 hours) between the cells of seven $\mathrm{LAB}$ strains and $\mathrm{AFM}_{1}$ was evaluated, as well as the differences between the removal efficiency of viable and non-viable (heat-killed) bacteria, and the stability of $A F M_{1} / L A B$ complex produced. The three $L A B$ strains with the highest percentage (> $33 \%$ ) of $A F M_{1}$ removal in the tests with PBS were reevaluated using UHT (ultra-high-temperature) skimmed milk spiked with $\mathrm{AFM}_{1}$. For these assays, only non-viable bacterial cells were used for checking the effect of temperature $\left(4^{\circ} \mathrm{C}\right.$ or $\left.37^{\circ} \mathrm{C}\right)$ on the toxin removal capacity during $15 \mathrm{~min}$. The mean $A_{F M}$ removal by LAB strains in PBS ranged from $5.60 \pm 0.45$ and $45.67 \pm 1.65 \%(n=3)$. Non-viable cells showed $\mathrm{AFM}_{1}$ removal percentages significantly higher than viable cells in both contact times (15 min. or 24 hours), although there were not significant differences between these contact times. The $A F M_{1} / L A B$ complex resulted from the tests with PBS was unstable, as $40.57 \pm 4.66$ to $87.37 \pm 1.82 \%$ of $A_{1} M_{1}$ retained by the bacteria were recovered in solution after washing the complex with PBS. The three $\mathrm{LAB}$ strains with the highest percentage of $A F M_{1}$ removal in the PBS assays (Lactobacillus rhamnosus, Lactobacillus delbrueckii spp. bulgaricus and Bifidobacterium lactis) showed no significant differences in the UHT skimmed milk assays at $37^{\circ} \mathrm{C}$. Only $B$. lactis had greater ability to remove $A F M_{1}$ in UHT milk at $4{ }^{\circ} \mathrm{C}$. The results demonstrated that the removal of $A F M_{1}$ by using $L A B$ in foods is viable to reduce the toxin concentrations until safe levels. However, additional studies are needed to investigate the mechanisms involved in the toxin removal by LAB aiming its application in food industries.

Keywords: Aflatoxin $\mathrm{M}_{1}$, Lactic acid bacteria, Decontamination, Milk 


\section{LISTA DE ILUSTRAÇÕES}

Figura 1 - Estrutura das principais aflatoxinas existentes..................................19

Figura 2 - Metabolismo da $\mathrm{AFB}_{1}$ no fígado. Adaptado de Inchem (1979)................25

Figura 3 - Fluxograma das análises para contagem de BAL................................36

Figura 4 - Fluxograma dos ensaios de remoção de $\mathrm{AFM}_{1}$ pelas BAL em TFS..........38

Figura 5 - Colunas de imunoafinidade acopladas a um manifold e bomba de vácuo.

Figura 6 - Processo de eluição da AFM 1 em coluna de imunoafinidade.

Figura 7 - Fluxograma dos ensaios de remoção de $\mathrm{AFM}_{1}$ pelas BAL em leite UHT.42

Figura 8 - Curvas de concentração bacteriana para as sete cepas de BAL..............45

Figura 9 - Placa de Petri com colônias típicas de Lactobacillus plantarum. .............45

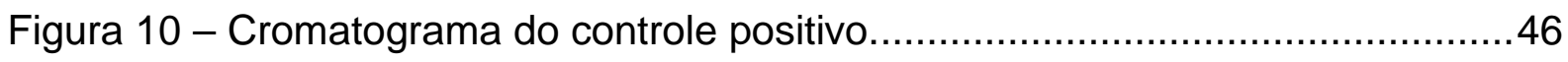

Figura 11 - Cromatograma de uma amostra de células viáveis de Lactobacillus plantarum no tempo de contato de 15 minutos. ..................................................4

Figura 12 - Cromatograma de uma amostra de células inviáveis de Enterococcus avium no tempo de contato de 15 minutos.........................................................4 


\section{LISTA DE TABELAS}

Tabela 1 - Níveis de aflatoxina $M_{1}$ determinados em leite e derivados no Brasil. ....21 Tabela 2 - Ingestão diária de $\mathrm{AFM}_{1}$ em todos os tipos de leite nas 5 regiões

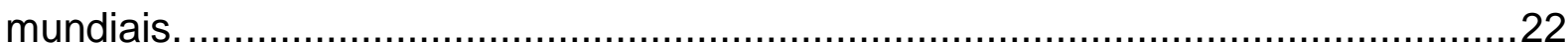

Tabela 3 - Cepas bacterianas utilizadas nos ensaios de remoção da AFM $\mathrm{A}_{1}$............34

Tabela 4 - Valores de absorbância e concentração bacteriana................................44

Tabela 5 - Percentual de remoção ${ }^{1}$ de AFM $_{1}$ em solução TFS ${ }^{2}$.............................48

Tabela 6 - Percentual ${ }^{1}$ de $\mathrm{AFM}_{1}$ recuperada em solução após lavagem com TFS ${ }^{2} .54$

Tabela 7 - Percentual de remoção ${ }^{1}$ da $\mathrm{AFM}_{1}$ em leite UHT desnatado ${ }^{2}$. .56 


\section{LISTA DE ABREVIATURAS, SÍMBOLOS E SIGLAS}

\begin{tabular}{|c|c|}
\hline $\mathrm{AFB}_{1}$ & Aflatoxina $\mathrm{B}_{1}$ \\
\hline $\mathrm{AFB}_{2}$ & Aflatoxina $\mathrm{B}_{2}$ \\
\hline AFBO & Aflatoxina $B_{1}-8,9$-epóxido \\
\hline $\mathrm{AFG}_{1}$ & Aflatoxina $\mathrm{G}_{1}$ \\
\hline $\mathrm{AFG}_{2}$ & Aflatoxina $\mathrm{G}_{2}$ \\
\hline $\mathrm{AFM}_{1}$ & Aflatoxina $\mathrm{M}_{1}$ \\
\hline BAL & Bactérias ácido-láticas \\
\hline${ }^{\circ} \mathrm{C}$ & Graus Celsius \\
\hline $\mathrm{CaCl}_{2}$ & Cloreto de cálcio \\
\hline CLAE & Cromatografia Líquida de Alta Eficiência \\
\hline EUA & Estados Unidos da América \\
\hline FAO & Organização das Nações Unidas para a Agricultura e Alimentação \\
\hline $\mathrm{Kg}$ & Kilograma \\
\hline $\mathrm{L}$ & Litro \\
\hline $\mathrm{Mg}$ & Miligrama \\
\hline $\mathrm{mL}$ & Mililitro \\
\hline MRS & Man, Rogosa \& Sharpe \\
\hline $\mathrm{NaCl}$ & Cloreto de sódio \\
\hline $\mathrm{Ng}$ & Nanograma \\
\hline $\mathrm{Nm}$ & Nanometro \\
\hline OMS & Organização Mundial de Saúde \\
\hline $\mathrm{pH}$ & Potencial hidrogeniônico \\
\hline rpm & Rotações por minuto \\
\hline TFS & Tampão fosfato salina \\
\hline UHT & Ultra-high-temperature \\
\hline UFC & Unidades formadoras de colônias \\
\hline$\mu g$ & Micrograma \\
\hline$\mu \mathrm{L}$ & Microlitro \\
\hline
\end{tabular}




\section{SUMÁRIO}

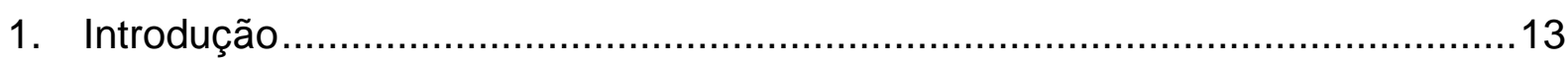

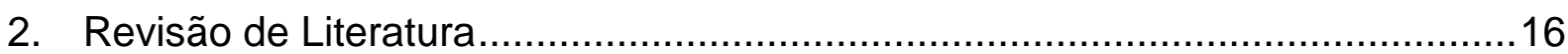

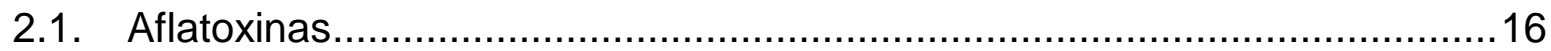

2.2. Propriedades toxicológicas das aflatoxinas...........................................19

2.3. Descontaminação de aflatoxinas por bactérias ácido-láticas ......................27

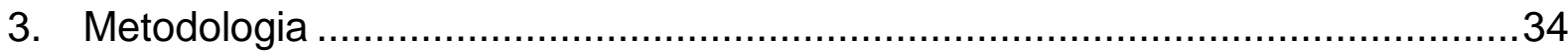

3.1. Bactérias, condições de cultivo e estimativa da concentração bacteriana ...34

3.2. Ensaio de remoção da aflatoxina $M_{1}$ em solução TFS .................................36

3.3. Quantificação da Aflatoxina $M_{1}$ em TFS através de CLAE..........................39

3.4. Ensaio de remoção da aflatoxina $M_{1}$ pelas BAL mais eficientes em leite UHT

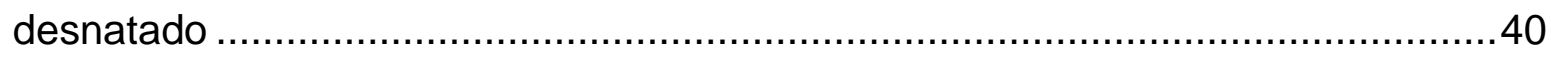

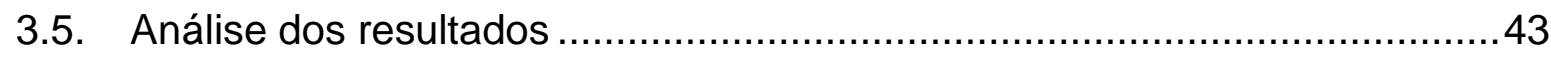

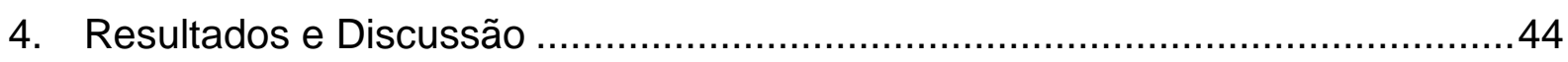

4.1. Curva de concentração bacteriana.........................................................4

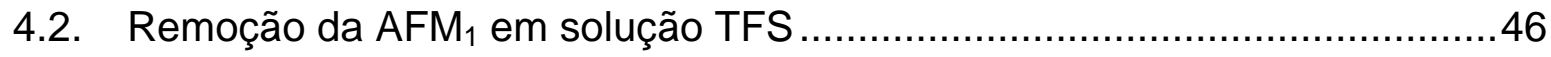

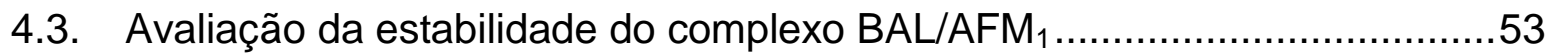

4.4. Remoção da $\mathrm{AFM}_{1}$ em leite UHT desnatado ..........................................55

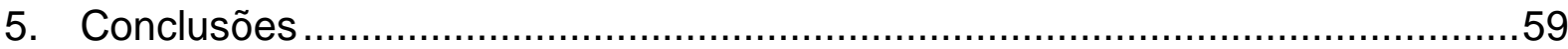

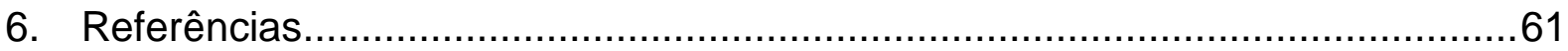




\section{Introdução}

As micotoxinas são metabólitos secundários de baixo peso molecular produzidos por fungos filamentosos. Dentre todas as micotoxinas existentes, as aflatoxinas, as quais são produzidas principalmente por Aspergillus flavus e Aspergillus parasiticus em condições de clima quente e úmido, destacam-se devido à sua ampla distribuição em alimentos e por suas propriedades tóxicas acentuadas. Existem, atualmente, 18 compostos similares designados pelo termo aflatoxina, porém a mais prevalente e tóxica é a aflatoxina $B_{1}\left(A F B_{1}\right)$, que quando ingerida por animais domésticos, entre eles o gado leiteiro, através do consumo de rações ou alimentos contaminados, sofre biotransformação hepática convertendo-se em aflatoxina $M_{1}\left(A F M_{1}\right)$, a qual é excretada no leite, tecidos e fluidos biológicos desses animais.

Historicamente, os níveis de contaminação de leite e derivados com AFM têm estado geralmente abaixo dos limites impostos pela legislação brasileira. No entanto, a alta incidência de $\mathrm{AFM}_{1}$ nesses produtos gera uma preocupação constante, pois o leite é o principal nutriente para o desenvolvimento de crianças, cuja sensibilidade é notável e potencialmente maior que em adultos. Deste modo, a ocorrência de $A F M_{1}$ no leite e nos produtos lácteos é considerada um grave problema de Saúde Pública. Além disso, os limites regulatórios impostos pelos países apresentam uma grande variação, sendo que geralmente os países em desenvolvimento são os que possuem os maiores níveis de tolerância.

As aflatoxinas podem causar efeitos carcinogênicos, mutagênicos, teratogênicos, hepatotóxicos e imunossupressivos em seres humanos e animais, sendo que a exposição crônica a essa toxina leva principalmente ao desenvolvimento do carcinoma hepatocelular. Além dos riscos à saúde, as aflatoxinas representam um sério problema financeiro, gerando perdas econômicas de milhões de dólares, pois proporcionam menor eficiência na produção agropecuária e industrial, como perda na qualidade, menor rendimento e defeitos nos produtos.

A preocupação relacionada aos impactos negativos das aflatoxinas sobre a saúde levou à investigação de estratégias para prevenir a sua formação em 
alimentos, bem como, para eliminar, inativar ou reduzir a biodisponibilidade destas toxinas em produtos contaminados. Considera-se como ideal a prevenção da contaminação já no campo, evitando-se a produção das aflatoxinas pelos fungos através de melhorias das práticas agrícolas e controle das condições de armazenamento dos produtos, além da utilização de outros meios, tais como a utilização de agentes antifúngicos e engenharia genética. Entretanto, as dificuldades de ordem prática para prevenir a contaminação tornam necessário o desenvolvimento de métodos de descontaminação de produtos alimentícios que sejam seguros, eficientes, específicos, apresentem custo-benefício e sejam ambientalmente corretos.

A utilização de microrganismos oferece uma alternativa interessante para o controle ou eliminação de aflatoxinas em alimentos e rações, resguardando sua qualidade e segurança, sendo que as bactérias ácido-láticas (BAL) vêm sendo amplamente estudadas e tem demonstrado grande capacidade de remoção da $A_{F} B_{1}$ em um meio contaminado. Essas bactérias são capazes de fermentar açúcares e tem o ácido lático como principal produto de seu metabolismo, o que faz com que constantemente sejam utilizadas como agentes conservadores em produtos alimentícios fermentados, aumentando sua vida de prateleira e suas propriedades sensoriais. Portanto, além de se utilizar as bactérias para a fermentação e conservação de alimentos, existe a possibilidade de utilizá-las como agentes descontaminantes de aflatoxinas, seja como parte de uma cultura starter ou como um componente purificado que pode ser adicionado ao alimento sem comprometer suas características finais.

Com base nos aspectos mencionados, e considerando-se que existem poucos dados na literatura sobre a capacidade de bactérias ácido-láticas em remover a $\mathrm{AFM}_{1}$ de um meio contaminado, estabeleceram-se os seguintes objetivos para o presente trabalho:

1) Determinar a capacidade de 7 cepas de BAL em remover a $A F M_{1}$ presente em solução tampão fosfato (TFS) contaminada, analisando-se a influência do tempo de contato (15 minutos e 24 horas) entre as células bacterianas e a micotoxina;

2) Verificar as diferenças entre a eficiência de remoção das células viáveis e inviabilizadas termicamente (fervura a $100^{\circ} \mathrm{C}$ por 1 hora) em TFS; 
3) Avaliar a estabilidade do complexo formado entre as $B A L$ e a $A F M_{1}$ através da lavagem dos pellets bacterianos produzidos em TFS;

4) Determinar a capacidade de remoção da $A F M_{1}$ pelas 3 cepas de BAL com maior percentual de remoção nos ensaios com TFS, em leite UHT (ultrahigh-temperature) desnatado artificialmente contaminado, utilizando-se apenas as células inviabilizadas termicamente e analisando-se o efeito da temperatura $\left(4^{\circ} \mathrm{C}\right.$ e $\left.37^{\circ} \mathrm{C}\right)$ pelo tempo de 15 minutos sobre essa capacidade de remoção. 


\section{Revisão de Literatura}

\subsection{Aflatoxinas}

Os fungos são organismos eucarióticos, unicelulares, multinucleados e heterotróficos, caracterizados por uma parede celular quitinosa, a maioria apresentando crescimento filamentoso e em colônias multicelulares (agrupados como micélio). Podem prosperar em quase todas as condições climáticas do mundo e em qualquer suporte sólido ou líquido, desenvolvendo-se em temperaturas entre $10^{\circ} \mathrm{C}$ e $40^{\circ} \mathrm{C}$, em um intervalo de $\mathrm{pH}$ de 4 a 8 e em atividade de água acima de 0,70 (podendo também crescer em uma superfície muito seca) (BHAT et al., 2010).

Atualmente, cerca de 100.000 fungos já foram identificados, dos quais mais de 400 podem ser considerados potencialmente toxigênicos e cerca de $5 \%$ são conhecidos por produzir compostos tóxicos ou classes de compostos que causam efeitos adversos em animais e humanos ao redor do mundo (BATA \& LASZTITY, 1999).

Esses compostos, denominados micotoxinas, são metabólitos secundários de baixo peso molecular produzidos pelos micélios ou esporos de fungos filamentosos, que não apresentam significância bioquímica no crescimento e desenvolvimento do fungo (GONÇALEZ et al., 2001; HUSSEIN \& BRASEL, 2001). D’Mello \& Macdonald (1997) sugerem que a produção das micotoxinas é geralmente limitada a um número relativamente pequeno de espécies de fungos, podendo ser toda a espécie produtora ou apenas uma cepa específica. Quanto mais complexo for o caminho da síntese de uma micotoxina, menor o número de espécies de fungos que a produzem.

O termo micotoxina é derivado da palavra grega "Mykes" que significa fungo e da palavra latina "Toxicum" que significa veneno ou toxina (GONÇALEZ et al., 2001). As micotoxinas são classificadas como o mais importante fator de risco nãoinfeccioso e crônico alimentar, sendo superior ao dos contaminantes sintéticos, toxinas de plantas, aditivos alimentares ou resíduos de pesticidas. Homem e animais 
podem ser levados a quadros de intoxicação aguda ou crônica através da ingestão de micotoxinas, sendo a condição patológica resultante desta ingestão a micotoxicose (NIERMAN et al., 2008). Fatores que afetam a magnitude dessa toxicidade em seres humanos ou animais incluem espécies, modos de ação, metabolismo e mecanismos de defesa (HUSSEIN \& BRASEL, 2001).

Analisando-se a história da humanidade, percebe-se que as micotoxinas afetam a produção agrícola desde seus primórdios, já que inúmeros casos de contaminação foram mencionados ao longo do tempo. Envenenamento por ergotamina é citado na Bíblia e postula-se que as toxinas produzidas por Fusarium e a zearalenona foram o motivo para a erradicação dos etruscos e da peste em Atenas no século $V$ a.C. Posteriormente, as toxinas do Fusarium causaram doenças em humanos e animais desde o período medieval na Europa até os tempos coloniais na América. Na Idade Média, uma epidemia de ergotismo ou Fogo de Santo Antônio, causado por toxinas produzidas por Claviceps purpúrea, levou muitas pessoas à morte em fogueiras acusadas de bruxaria, já que os sintomas dessa intoxicação eram alucinações e inchaço dos membros com sensação de queimação, o que não era compreendido por religiosos da época. Há também especulações de que mortes súbitas misteriosas de arqueólogos ao entrar em tumbas egípcias foram causadas por inalação de micotoxinas, a ocratoxina A em particular (BARTOSZEK, 2006).

Atualmente, cerca de 400 tipos de micotoxinas já foram descobertos, sendo estas geralmente divididas em grupos com base em similaridades estruturais e seus maiores efeitos tóxicos (BHAT et al., 2010). De todas as micotoxinas isoladas, uma das mais conhecidas e amplamente distribuídas em alimentos, e que comprovadamente têm propriedades tóxicas acentuadas são as aflatoxinas (AN, 2005). Estas são predominantemente produzidas por Aspergillus flavus e Aspergillus parasiticus, mas também podem ser produzidas por outras cepas como A. nominus, A. tamarii e A. pseudotamarii (ALBERTS et al., 2006).

A palavra aflatoxina é derivada da combinação de "a" para o gênero Aspergillus, "fla" devido à espécie flavus e "toxina" que significa veneno. Sua descoberta foi no ano de 1960 devido à ocorrência de um grave surto causado por uma doença desconhecida ("Doença X"), que resultou na morte de mais de 100 mil perus e outros animais, os quais tinham sido alimentados com amendoim brasileiro contaminado com $A$. flavus. Entretanto, não apenas o amendoim pode sofrer 
contaminação por fungos aflatoxigênicos, mas também outros alimentos como cereais (milho, sorgo, milheto, arroz, trigo), especiarias (pimenta, coentro, açafrão, gengibre), oleaginosas (soja, girassol, semente de algodão) e frutas secas (pistache, amêndoas, nozes, castanha do Brasil, coco) (CHU, 1991; BHAT et al., 2010). Destaca-se que a contaminação pode ocorrer, direta ou indiretamente, em qualquer momento durante a produção, colheita, processamento, transporte e armazenamento (PARK \& LIANG, 1993).

As aflatoxinas apresentam ocorrência no mundo inteiro, principalmente nas áreas de clima tropical e subtropical, sendo que as espécies de Aspergillus são capazes de crescer em uma ampla variedade de substratos e sob diversas condições ambientais. A formação da toxina nos produtos agrícolas ocorre em condições de tempo quente e úmido, e em instalações de armazenagem deficiente ou inadequada, sendo que os fatores mais importantes que influenciam 0 crescimento e a produção de aflatoxinas são a umidade relativa, que na maioria dos casos a faixa requerida é de 88\% a 95\% (PARK \& LIANG, 1993), e a temperatura, sendo a ótima para o crescimento do fungo de $36^{\circ} \mathrm{C}$ a $38^{\circ} \mathrm{C}$ e para a produção máxima de toxina de $25^{\circ} \mathrm{C}$ a $27^{\circ} \mathrm{C}$ (ABBAS, 2005).

Outros fatores que podem ainda influenciar a produção de aflatoxinas são: composição do substrato, pH, atmosfera (teor de oxigênio e de dióxido de carbono), competição microbiana, danos mecânicos, linhagem do fungo contaminante, especificidade e variação da cepa, instabilidade das propriedades toxigênicas, estresse da planta, infestação por insetos e uso de fungicidas ou fertilizantes (GONÇALEZ et al., 2001; HUSSEIN \& BRASEL, 2001; MAGAN \& OLSEN, 2006). É importante lembrar que o nível de contaminação é cumulativo, portanto a época de colheita e as condições de secagem e armazenamento podem desempenhar um papel igualmente importante na produção de aflatoxina (PRANDINI et al., 2009). 


\subsection{Propriedades toxicológicas das aflatoxinas}

São conhecidos, atualmente, 18 compostos similares designados pelo termo aflatoxina, porém, os principais tipos de interesse médico-sanitário são identificados, com base na sua fluorescência sob a luz ultravioleta $(B=$ Blue e $G=$ Green), como aflatoxina $B_{1}\left(A F B_{1}\right), B_{2}\left(A F B_{2}\right), G_{1}\left(A F G_{1}\right)$ e $G_{2},\left(A F G_{2}\right)$, sendo que destes compostos a $A F B_{1}$ é a mais prevalente e tóxica (OLIVEIRA \& GERMANO, 1997).

Quando a $\mathrm{AFB}_{1}$ é ingerida por animais domésticos, entre eles o gado leiteiro, através do consumo de rações ou alimentos contaminados, parte dela é degradada no rúmen por seus microrganismos, resultando na formação de aflatoxicol. A parte restante é absorvida pelo trato digestivo por difusão passiva (FINK-GREMMELS, 2008) e sofre biotransformação hepática convertendo-se em aflatoxina $M_{1}\left(A F M_{1}\right)$, sendo, portanto, uma forma hidroxilada da $\mathrm{AFB}_{1}$ que é excretada no leite, tecidos e fluidos biológicos desses animais (OATLEY et al., 2000; PELTONEM et al., 2001; MURPHY et al., 2006). Creppy (2002) relata que da totalidade de $\mathrm{AFB}_{1}$ ingerida através da ração, aproximadamente $0,3 \%$ a $6,2 \%$ é transformada em $\mathrm{AFM}_{1}$ no leite, e Bakirci (2001) afirma que existe ainda uma relação linear entre a quantidade de $\mathrm{AFM}_{1}$ no leite e a ração contaminada por $\mathrm{AFB}_{1}$ consumida pelos animais. Observase na Figura 1 as estruturas das principais aflatoxinas existentes.

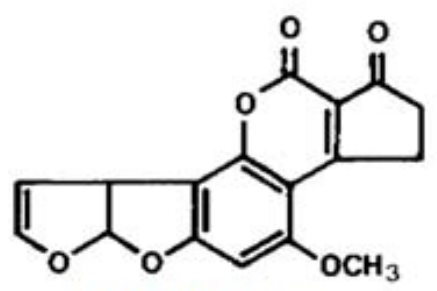

Aflatoxina $\mathrm{B}_{1}$

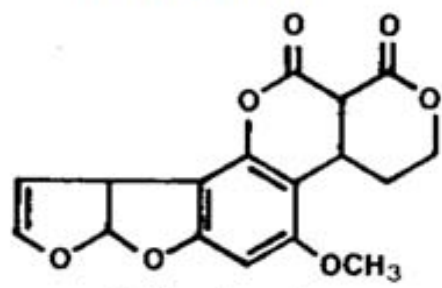

Aflatoxina $\mathrm{G}_{1}$

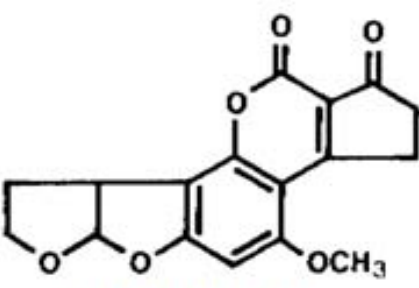

Aflatoxina $\mathrm{B}_{2}$

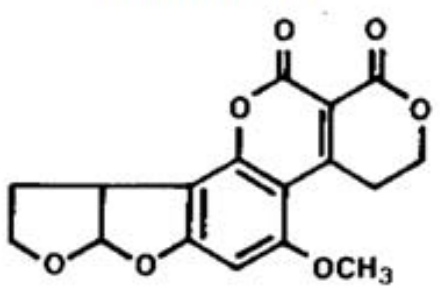

Aflatoxina $\mathrm{G}_{2}$

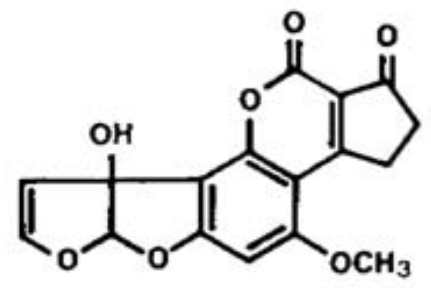

Aflatoxina $M_{1}$

Figura 1 - Estrutura das principais aflatoxinas existentes. 
Muitas pesquisas têm sido realizadas para a determinação dos níveis de contaminação por $\mathrm{AFM}_{1}$ em leite e seus derivados em diversos países do mundo. $\mathrm{Na}$ Turquia, Çelik et al. (2005) realizaram análises para detecção de $\mathrm{AFM}_{1}$ em leite pasteurizado e encontraram que $88,23 \%$ das amostras eram positivas com contaminação entre 5,2 e 127,5 ng/L. Galvano et al. (1998) detectaram, na Itália, $\mathrm{AFM}_{1}$ em mais de $80 \%$ das amostras de leite fluido, leite em pó e iogurte, com níveis médios de $10 \mathrm{ng} / \mathrm{L}, 21 \mathrm{ng} / \mathrm{kg}$ e $18 \mathrm{ng} / \mathrm{L}$, respectivamente. Kim et al. (2000) analisaram leite pasteurizado, fórmula infantil, leite em pó e iogurte, na Coréia do Sul, observando incidências de 76, 85, 75 e 83\%, respectivamente; os autores obtiveram níveis médios de contaminação de 18, 46, 200 e 29 ng/kg, respectivamente.

No Brasil, os dados referentes à incidência de $A F M_{1}$ em leite e derivados indicam que a freqüência da toxina em nossas condições é alta, porém de modo geral em níveis relativamente baixos, conforme pode ser observado em alguns trabalhos recentes apresentados na Tabela 1.

A partir da observação de que o consumo de rações contaminadas por $\mathrm{AFB}_{1}$ por animais leiteiros pode levar à excreção de $\mathrm{AFM}_{1}$ no leite, destacam-se alguns fatores nutricionais e fisiológicos que podem influenciar na taxa de conversão da $A F B_{1}$ para a $A F M_{1}$, tais como o regime de alimentação, a taxa de ingestão, a saúde do animal, a capacidade de biotransformação hepática, a presença de infecções no úbere, o período de lactação (no início da lactação essa taxa é cerca de 3,5 vezes maior em comparação com a fase de lactação avançada) e a produção de leite. Portanto, a taxa de absorção de aflatoxinas e a excreção de $\mathrm{AFM}_{1}$ no leite variam entre cada animal, de dia para dia, e de ordenha para ordenha (FINK-GREMMELS, 2008).

Prandini et al. (2009) explica que vacas que ingerem uma quantidade de $\mathrm{AFB}_{1}$ menor que $40 \mu \mathrm{g} /$ cabeça/dia produzem um leite com teor de $\mathrm{AFM}_{1}$ menor que 0,05 $\mu \mathrm{g} / \mathrm{kg}$, e que as reações de produção de $A F M_{1}$ são muito rápidas, pois a $A F M_{1}$ aparece no leite 2 a 3 dias após a ingestão da ração contaminada, assim como o nível de $\mathrm{AFM}_{1}$ no leite é reduzido a zero também em 2 a 3 dias, quando o animal é alimentado com uma dieta sem aflatoxinas. 
Tabela 1 - Níveis de aflatoxina $M_{1}$ determinados em leite e derivados no Brasil.

Concentração

\begin{tabular}{|c|c|c|c|c|}
\hline Alimento & $\begin{array}{c}\text { Faixa } \\
\text { (ng/L ou kg) }\end{array}$ & $\begin{array}{l}\text { Média } \pm \text { DP } \\
\text { (ng/L ou kg) }\end{array}$ & NC/NA (\%) ${ }^{a}$ & Referência \\
\hline Queijo Minas & $20-6.920$ & $\mathrm{NE}$ & $66 / 75$ (88) & $\begin{array}{l}\text { Prado et al. } \\
(2000)\end{array}$ \\
\hline $\begin{array}{c}\text { Leite pasteurizado e } \\
\text { UHT }\end{array}$ & $15-500$ & NE & $111 / 139(80)$ & $\begin{array}{l}\text { Garrido et al. } \\
\text { (2003) }\end{array}$ \\
\hline Leite pasteurizado tipo $\mathrm{A}$ & $11-251$ & $60 \pm 80$ & $37 / 48(77)$ & Oliveira et al. \\
\hline Leite pasteurizado tipo $B$ & & $56 \pm 63$ & & (2006) \\
\hline Leite pasteurizado tipo $\mathrm{C}$ & & $64 \pm 41$ & & \\
\hline Leite UHT & & $75 \pm 48$ & & \\
\hline $\begin{array}{c}\text { Leite cru, pasteurizado e } \\
\text { UHT }\end{array}$ & $2-26$ & NE & $79 / 107(73,8)$ & $\begin{array}{c}\text { Shundo \& Sabino } \\
\text { (2006) }\end{array}$ \\
\hline Leite de cabra & $11-161$ & $62 \pm 40$ & $25 / 36(69,4)$ & $\begin{array}{c}\text { Oliveira \& Ferraz } \\
\text { (2007) }\end{array}$ \\
\hline Leite cru & $10-645$ & $104 \pm 138$ & & $\begin{array}{l}\text { Oliveira et al. } \\
\qquad(2008)\end{array}$ \\
\hline $\begin{array}{l}\text { Leite em pó, } \\
\text { pasteurizado e UHT }\end{array}$ & $10-200$ & 31 & $\begin{array}{c}119 / 125 \\
(95,2)\end{array}$ & $\begin{array}{l}\text { Shundo et } \\
\text { al.(2009) }\end{array}$ \\
\hline
\end{tabular}

De acordo com Galvano et al. (1996) e Prandini et al. (2009), o leite é o alimento que demonstra o maior potencial para a introdução de resíduos de aflatoxina na alimentação humana. Além disso, como o leite é o principal nutriente para o crescimento de crianças, cuja sensibilidade é notável e potencialmente maior que em adultos, a ocorrência de $\mathrm{AFM}_{1}$ no leite materno e nos produtos lácteos é um dos mais graves problemas de higiene alimentar. Os mesmos autores ressaltam que os tratamentos térmicos do leite, como pasteurização e secagem, não causam a redução da $A F M_{1}$, já que esta apresenta termorresistência; e que a distribuição da $\mathrm{AFM}_{1}$ no leite não é homogênea, estando $80 \%$ dela localizada na parte não gordurosa do leite ligada à caseína. Assim, nos processos que envolvem a separação de gordura, a $\mathrm{AFM}_{1}$ predominará na fração não gordurosa, o que pode 
ser explicado devido ao seu caráter semipolar, e nos processos de fabricação de queijos ocorrerá um fator de enriquecimento da $A F M_{1}$, pois sua concentração é aproximadamente 3 vezes maior em queijos macios e 5 vezes maior em queijos de massa dura comparados ao leite.

Kuiper-Goodman (1990) estabeleceu uma ingestão diária tolerável de $\mathrm{AFM}_{1}$ para os seres humanos em 0,2 $\mathrm{ng} / \mathrm{kg}$ de peso coporal, sendo assim, uma pessoa de $60 \mathrm{~kg}$ ingeriria cerca de $12 \mathrm{ng} /$ dia de $\mathrm{AFM}_{1}$. Observa-se, na Tabela 2, os valores médios do consumo de leite e da ingestão diária de $\mathrm{AFM}_{1}$ divulgados no relatório da FAO/OMS (Organização das Nações Unidas para Agricultura e Alimentação / Organização Mundial de Saúde) em 2001 (JEFCA, 2001). Pode-se perceber que a região da África é a que apresenta a menor ingestão diária de $\mathrm{AFM}_{1}$ por pessoa $(0,1$ ng/pessoa/dia) e que a região do Oriente Médio é a que apresenta a maior ingestão diária por pessoa (12 ng/pessoa/dia), cujo valor permanece, ainda, dentro do limite tolerável estabelecido acima. Já Revankar (2003) estima que o consumo de aflatoxinas por humanos varie entre 0 e 30.000 ng/kg/dia com uma ingestão média de 10 a $200 \mathrm{ng} / \mathrm{kg} / \mathrm{dia}$.

Tabela 2 - Ingestão diária de $\mathrm{AFM}_{1}$ em todos os tipos de leite nas 5 regiões mundiais.

\begin{tabular}{ccccc}
\hline Dieta regional $^{*}$ & $\begin{array}{c}\text { Ingestão de } \\
\text { leite }(\mathrm{kg} / \mathrm{dia})\end{array}$ & $\begin{array}{c}\text { Aflatoxina no } \\
\text { leite }(\mu \mathrm{g} / \mathrm{kg})\end{array}$ & \multicolumn{2}{c}{\begin{tabular}{c} 
Ingestão de aflatoxina \\
\cline { 5 - 5 }
\end{tabular}} \\
& & & $\mathrm{ng} /$ pessoa/dia** & $\mathrm{ng} / \mathrm{kg}$ \\
Européia & 0,290 & 0,023 & 6,8 & 0,110 \\
América Latina & 0,160 & 0,022 & 3,5 & 0,058 \\
Extremo Oriente & 0,032 & 0,360 & 12,0 & 0,200 \\
Oriente Médio & 0,120 & 0,005 & 0,6 & 0,100 \\
África & 0,042 & 0,022 & 0,1 & 0,002
\end{tabular}

*Países de cada região que forneceram dados para o cálculo das médias: Européia (Canadá, nove membros da União Européia, Noruega, Polônia e Estados Unidos), América Latina (Argentina, Brasil e Uruguai), Extremo Oriente (Índia, Indonésia, Filipinas, República da Coréia e Tailândia), Oriente Médio (Grécia e Emirados Árabes Unidos) e África (Egito).

**Pessoa com peso corporal de $60 \mathrm{~kg}$.

Fonte: JEFCA, 2001. 
Sérios riscos à saúde humana e animal podem ser causados pelas aflatoxinas, pois estas apresentam efeitos tóxicos, carcinogênicos, mutagênicos, teratogênicos, hepatotóxicos e imunosupressivos (PIERIDES et al., 2000; HERNANDEZ-MENDOZA et al., 2009a), sendo estes influenciados pela variação da espécie, sexo, idade, estado nutricional e os efeitos de outros produtos químicos, além da dose e o período de exposição do organismo à toxina (MISHRA \& DAS, 2003).

Em 1993, a International Agency for Research on Cancer (IARC, 1993), classificou a $A F B_{1}$ como pertencente ao Grupo 1, carcinogênica para humanos, e a $\mathrm{AFM}_{1}$ como pertencente ao grupo $2 \mathrm{~B}$, possivelmente carcinogênica para humanos. Entretanto, em 2002, após a realização de novas pesquisas e uma reconsideração de sua carcinogenicidade, a $\mathrm{AFM}_{1}$ foi reclassificada passando do grupo 2 para 0 grupo 1 , mesmo sendo aproximadamente 10 vezes menos carcinogênica que $A F B_{1}$ (IARC, 2002).

A aflatoxicose é o envenenamento resultante da ingestão de níveis moderados a altos de aflatoxinas em alimentos contaminados. A aflatoxicose aguda resulta em icterícia progressiva e rápida, edema nos membros, dores, vômitos, necrose, cirrose, ou em casos graves, insuficiência hepática aguda e morte (NIERMAN et al., 2008). Pode ser causada pela ingestão de aproximadamente $10 \mathrm{a}$ $20 \mathrm{mg}$ de aflatoxina em um adulto, tendo, de acordo com a $\mathrm{DL}_{50}$, a seguinte ordem de toxicidade: $A F B_{1}>A F M_{1}>A F G_{1}>A F B_{2}>A F G_{2}$ (LACIAKOVÁ et al., 2008). Já a aflatoxicose crônica resulta em câncer, supressão imunológica, e outras condições patológicas, sendo o fígado o órgão alvo primário (NIERMAN et al., 2008).

Hussein \& Brasel (2001) explicam que para os seres humanos, o maior risco das aflatoxinas é a exposição crônica causando o carcinoma hepatocelular, que pode ser agravado pelo vírus da hepatite A. Os mesmos autores também comentam que aflatoxinas foram encontradas em tecidos de crianças que sofrem de síndrome de Reye (encefalopatia com lesões graves nos rins e fígado após gripe ou varicela) e de Kwashiorkor (desnutrição energético-protéica), considerando-se, portanto, ser um fator que contribui para essas doenças.

Entre os animais, os monogástricos, como aves e suínos, são os que apresentam maior risco de contaminação, já que grande parte de sua dieta basal é constituída de cereais, além de estes animais não terem reservatório ruminal com 
alguns tipos de microorganismos que podem degradar as toxinas antes que sejam absorvidas pelo intestino. Os principais sintomas da aflatoxicose aguda em mamíferos incluem letargia, ataxia, pêlos arrepiados e inchaço do fígado, enquanto que com a exposição crônica, os sintomas incluem a redução da eficiência alimentar e da produção de leite e diminuição do apetite (PARK et al., 2000; BHAT et al., 2010).

$A A B_{1}$ é metabolizada pelo fígado através do sistema enzimático citocromo P450, podendo seguir 4 diferentes caminhos metabólicos: O-desalquilação a aflatoxina $P_{1}$, quetoredução a aflatoxicol, epoxidação a $A F B_{1}$-8,9-epóxido (AFBO) (altamente tóxico, mutagênico e carcinogênico), ou, ainda, hidroxilação a $A F M_{1}$ (altamente tóxica), aflatoxina $Q_{1}$ ou aflatoxina $B_{2 a}$ (ambas relativamente não tóxicas). Assim, as principais reações no metabolismo das aflatoxinas são hidroxilação, oxidação e desmetilação (WU et al., 2009), as quais podem ser observadas mais claramente na Figura 2.

Depois de metabolizada, a AFBO pode se ligar às macromoléculas celulares, incluindo o material genético, como, por exemplo, as proteínas e DNA, formando adutos com os ácidos nucléicos (MURPHY et al., 2006). Os adutos formados convertem-se em um anel aberto estável derivado da formamidopirimidina, sendo que o reparo dessas lesões leva ao aparecimento de mutações genéticas e câncer. Metabólitos hidroxilados e outras aflatoxinas que ocorrem naturalmente são substratos pobres para a reação de epoxidação e, consequentemente, são menos mutagênicos e carcinogênicos (BARTOSZEK, 2006). A excreção de alguns desses compostos na urina de pessoas infectadas, não só serve como prova de que os seres humanos têm os caminhos bioquímicos necessários para a carcinogênese, mas também oferece um biomarcador confiável para a exposição à AFB $_{1}$ (MURPHY et al., 2006). 


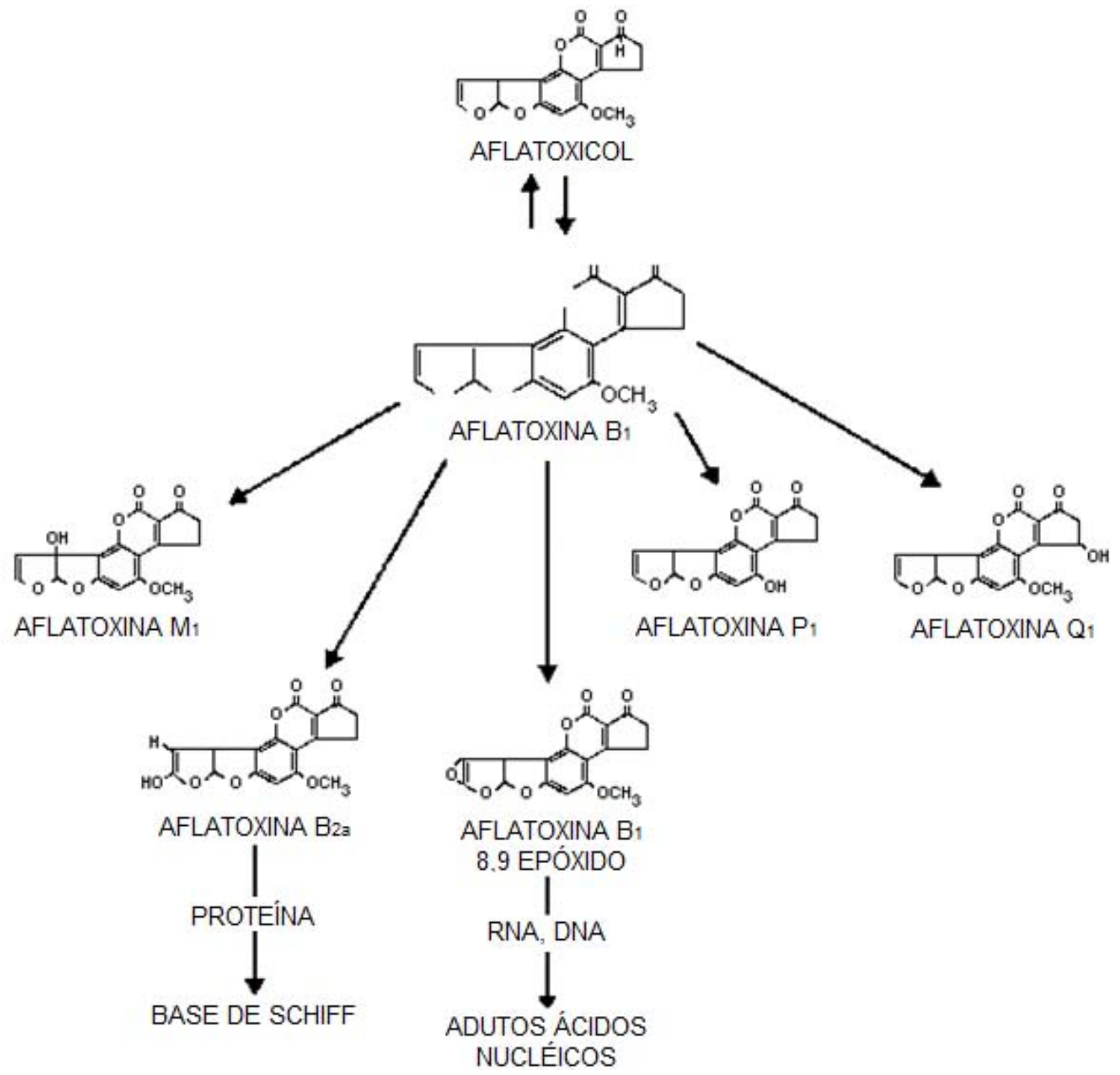

Figura 2 - Metabolismo da AFB 1 no fígado. Adaptado de Inchem (1979).

Além dos riscos à saúde, as aflatoxinas representam um sério problema à economia, pois os danos causados por elas estão relacionados a uma menor eficiência na produção agropecuária e industrial, como perda na qualidade, bem como a um menor rendimento e defeitos nos produtos (BATA \& LASZTITY, 1999; HASKARD et al., 2001). Alberts et al. (2009) relatam que, em alguns estados dos Estados Unidos da América (EUA), as perdas econômicas na agropecuária chegam a 100 milhões de dólares. Já Oluwafemi \& Da Silva (2009) afirmam que essas perdas devido à contaminação por fungos e micotoxinas são superiores a 1,6 bilhões de dólares nos EUA e que as nações africanas perdem cerca de 670 bilhões 
de dólares devido a bloqueios no comércio de alimentos contaminados com aflatoxinas.

O potencial risco que as aflatoxinas causam para a saúde humana tem levado à criação de programas de monitoramento da toxina em diversas matérias-primas, bem como a ações de regulamentação por quase todos os países ao redor do mundo (CHU, 1991). Uma pesquisa realizada pela Organização das Nações Unidas para Agricultura e Alimentação (FAO) no ano de 2002 apontou que aproximadamente 100 países possuem legislação específica para a presença de aflatoxinas em alimentos, produtos lácteos e/ou rações, sendo que a população total desses países representava aproximadamente $90 \%$ da população mundial. A mesma pesquisa ainda mostrou que as legislações para aflatoxina estão ficando cada vez mais diversas e detalhadas, incluindo métodos de amostragem e metodologia analítica (VAN EGMOND \& JONKER, 2004).

Nos países que possuem esse tipo de legislação, os níveis de tolerância para aflatoxina total (soma das aflatoxinas $B_{1}, B_{2}, G_{1}$ e $G_{2}$ ) variam entre 1 e $35 \mu \mathrm{g} / \mathrm{kg}$ para alimentos, sendo o valor médio de $10 \mu \mathrm{g} / \mathrm{kg}$, e variam entre zero e $50 \mu \mathrm{g} / \mathrm{kg}$ para rações, com valor médio de $20 \mu \mathrm{g} / \mathrm{kg}$. Para $\mathrm{AFM}_{1}$ em leite, os níveis de tolerância estão entre 0,05 e $0,5 \mu \mathrm{g} / \mathrm{kg}$, sendo que a maioria dos países adota o limite de 0,05 $\mu \mathrm{g} / \mathrm{kg}$ (ABBAS, 2005).

No Brasil, as aflatoxinas são as únicas micotoxinas cujos níveis máximos em alimentos estão previstos na legislação. Além da Portaria No.183, de 21 de março de 1996, do Ministério da Agricultura, que internalizou as normas do MERCOSUL GMC/RES. No.56/94, adotando limites máximos admissíveis de aflatoxinas no leite, amendoim e milho (BRASIL, 1996), o Ministério da Saúde, através da Resolução 274, de 15 de outubro de 2002, estabeleceu limites máximos de AFM $_{1}$ admissíveis no leite fluido $(0,5 \mu \mathrm{g} / \mathrm{L})$ e em pó $(5,0 \mu \mathrm{g} / \mathrm{kg})$, assim como os limites máximos para aflatoxina total em amendoim e milho $(20,0 \mu \mathrm{g} / \mathrm{kg})(B R A S I L, 2002)$. 


\subsection{Descontaminação de aflatoxinas por bactérias ácido-láticas}

A preocupação relacionada aos impactos negativos das aflatoxinas sobre a saúde levou à investigação de estratégias para prevenir a sua formação em alimentos, bem como, para eliminar, inativar ou reduzir a biodisponibilidade destas toxinas em produtos contaminados (HERNANDEZ-MENDOZA et al., 2009a).

Para prevenir a contaminação utilizam-se métodos de melhoria das práticas agrícolas, agentes antifúngicos, engenharia genética e controle das condições de armazenamento (GONÇALEZ et al., 2001). Para reduzir a biodisponibilidade, utilizase a enteroadsorção, que é feita através da adição na dieta de compostos adsorventes nutricionalmente inertes, os quais são agentes sequestrantes de micotoxinas, pois evitam sua absorção no trato gastrointestinal dos animais, impossibilitando a sua distribuição para o órgão-alvo (GRATZ et al., 2005; SEKIYAMA et al., 2007), sendo que esse método tem uma aplicação prática limitada devido à questão de segurança dos adsorventes usados, já que podem alterar o valor nutricional adsorvendo minerais e vitaminas e podem produzir dioxinas (HUSSEIN \& BRASEL, 2001), além da dificuldade de aplicação em alimentos para humanos (EL-NEZAMI et al., 1998a).

Por último, para eliminar ou inativar, isto é, para realizar a descontaminação utilizam-se métodos físicos, químicos e biológicos, os quais devem ter como características a completa inativação, destruição ou remoção da toxina; não produzir ou deixar resíduos tóxicos nos alimentos, preservando seu valor nutritivo e palatabilidade; destruir os esporos e as micelas de fungos para prevenir a produção ou o reaparecimento da toxina; não modificar as propriedades físicas do alimento significativamente, possuir um custo acessível e ser de fácil utilização (BATA \& LASZTITY, 1999; MAGAN \& OLSEN, 2006).

Os métodos físicos de descontaminação de micotoxinas envolvem procedimentos como inativação térmica, luz ultravioleta, radiação ionizante ou extração com solventes, e os métodos químicos utilizam agentes que degradam estruturalmente as micotoxinas, como o uso de cloração (hipoclorito de sódio e cloro gasoso), agentes oxidantes (peróxido de hidrogênio, ozônio e bissulfito de sódio) ou agentes hidrolíticos (ácidos, álcalis e amônia). Entretanto, ambos os métodos 
possuem desvantagens, seja por não removerem eficientemente, ou então, por apresentarem altos custos ou proporcionarem perdas nutricionais e organolépticas aos produtos (LINE \& BRACKETT, 1995; EL-NEZAMI et al., 1998b). Os métodos biológicos decorrem da atuação de microorganismos, como por exemplo, leveduras, fungos filamentosos, bactérias, algas, entre outros, sobre as micotoxinas através de mecanismos como competição por nutrientes e espaço, interações e antibiose (FAZELI et al., 2009).

A biodegradação de aflatoxinas utilizando microorganismos oferece uma alternativa atrativa para o controle ou eliminação de aflatoxinas em alimentos e rações, resguardando sua qualidade e segurança (ALBERTS et al., 2009), além de poder ser utilizada como um apelo de mais "natural", já que a resistência do consumidor a tratamentos químicos continua a crescer (BATA \& LASZTITY, 1999). Os métodos de descontaminação biológicos estão sendo amplamente estudados e podem ser uma escolha muito promissora, desde que apresentem eficiência, especificidade, custo-benefício e que sejam ambientalmente corretos (WU et al., 2009). Dentre todos os tipos de microrganismos existentes e que podem ser utilizados para a remoção de aflatoxinas do meio contaminado, as bactérias ácidoláticas (BAL) são umas das mais estudadas e que apresentam resultados mais promissores.

As BAL são um grande grupo de bactérias geneticamente diversas, que além de produzirem o ácido lático como principal produto do seu metabolismo, possuem características comuns como serem gram-positivas, não-esporogênicas, não se locomoverem espontaneamente, e serem catalase e oxidase negativas. Portanto, elas crescem anaerobicamente, mas são aero-tolerantes. Além disso, elas obrigatoriamente fermentam açúcares e tendem a ser nutricionalmente exigentes, freqüentemente requerendo aminoácidos específicos e vitaminas do complexo $B$ como fatores de crescimento (WALSTRA et al., 2006). Vários gêneros de BAL, como Lactobacillus, Bifidobacterium e Lactococcus, são conhecidos por sua capacidade de atuar como agentes conservadores em produtos alimentícios fermentados, como vegetais, cereais, produtos lácteos e carnes (PELTONEM et al., 2001).

A fermentação proporciona uma maior vida de prateleira e melhora das propriedades sensoriais e nutricionais do produto, pois através do processo fermentativo do açúcar tem-se o abaixamento do $\mathrm{pH}$ inibindo o crescimento de 
microrganismos deteriorantes e patogênicos, também ocorrendo a hidrólise de proteínas que proporciona melhora na textura e sabor, síntese de componente aromáticos, síntese de agentes texturizantes que influenciam na consistência do produto, e produção de componentes inibitórios (SALMINEN, 2004; SYBESMA \& HUGENHOLTZ, 2004). Esta inibição é, em parte, devido aos produtos finais da fermentação, como ácido lático, diacetil, acetaldeído e ácido acético, que podem acumular para níveis inibitórios em certos alimentos e bebidas. Em outros casos, a inibição pode, ainda, ser causada por subprodutos secundários da atividade metabólica, tais como peróxido de hidrogênio ou bacteriocinas (ONILUDE et al., 2005).

Portanto, dois aspectos podem ser considerados quando se utilizam as BAL: a fermentação e a antibiose. No primeiro caso, a cultura iniciadora adicionada age sobre o substrato, resultando em benefícios ao alimento, e no segundo caso, a cultura iniciadora deve inibir o desenvolvimento de microrganismos indesejáveis que causam danos ao produto ou à saúde humana.

Fuchs et al. (2008) comentam que um dos efeitos identificados das BAL é a proteção contra toxinas contidas nos alimentos, como aminas heterocíclicas aromáticas, hidrocarbonetos policíclicos aromáticos, espécies reativas de oxigênio e micotoxinas. Neste último caso, estudos têm demonstrado que as BAL possuem a propriedade de inibir a biossíntese de aflatoxinas, ou ainda, possuem a habilidade de remover a micotoxina do meio minimizando a ação desta.

Ressalta-se que com 0 aumento do interesse na produção de alimentos probióticos em todo o mundo, a seleção de culturas de BAL com características probióticas e com alta capacidade de remoção das micotoxinas poderá ajudar a reduzir os riscos de exposição a essas toxinas através dos alimentos, caracterizando-se como uma linha de pesquisa bastante promissora na área de micotoxicologia. Shetty \& Jespersen (2006) afirmam que cepas de leveduras e BAL possuem alta capacidade de remoção de micotoxinas e podem ser usadas como parte de culturas starter na fermentação de alimentos e bebidas, tendo, portanto, capacidade fermentativa e descontaminante, e que componentes purificados dessas mesmas cepas podem ser usados em pequenas quantidades como aditivos alimentícios sem comprometerem as características do produto final. 
Um dos primeiros estudos nessa área foi o realizado na década de 1960 por Ciegler et al. (1966), quando os autores avaliaram a habilidade de cerca de 1.000 tipos de microrganismos em degradar a aflatoxina, entre eles leveduras, fungos filamentosos, bactérias, actinomicetos, algas e esporos de fungos, sendo que destes apenas a bactéria Flavobacterium aurantiacum B-184 (conhecida atualmente como Nocardia corynebacterioides) foi capaz de remover irreversivelmente as aflatoxinas da solução.

Depois desse estudo, muitos outros foram realizados, entretanto, os mais significativos na área começaram a aparecer após a década de 1990. El-Nezami et al. (1998b) avaliaram a ação de 7 diferentes tipos de bactérias sobre a $A F B_{1}$ e encontraram que algumas cepas de Lactobacillus (L. rhamnosus $G G$ e $L$. rhamnosus LC-705) conseguiram remover eficientemente boa parte da micotoxina do meio, alcançando até cerca de $80 \%$ de remoção. Haskard et al. (2001) analisaram 9 cepas de Lactobacillus spp. e também chegaram ao resultado de que L. rhamnosus GG e L. rhamnosus LC-705 foram mais eficientes na remoção da $\mathrm{AFB}_{1}$, chegando a 78,9\% e 76,5\%, respectivamente. Peltonem et al. (2001) estudaram 15 tipos de BAL, dos gêneros Lactobacillus e Lactococcus, e 5 tipos de bifidobactérias, e obtiveram resultados de remoção com a $\mathrm{AFB}_{1}$ variando de $5,6 \%$ a $59,7 \%$, sendo que as cepas de Lactobacillus amylovorus (CSCC 5160 e CSCC 5197) e L. rhamnosus LC 1/3 foram as que apresentaram melhores resultados, $59,7 \%, 57,8 \%$ e $54,6 \%$ respectivamente. Oatley et al. (2000) observaram que diferentes cepas de bifidobactérias removeram de $37 \%$ a $46 \%$ da $\mathrm{AFB}_{1}$, e que Staphylococcus aureus e Escherichia coli removeram $46 \%$ e $37 \%$, respectivamente.

Pode-se observar que dentro de um dado gênero e até mesmo de uma determinada espécie, nem todas as cepas são equivalentes em termos de remoção da toxina, ao contrário, a capacidade de remoção de aflatoxina é uma característica apenas de linhagens específicas, com sua eficácia variando acentuadamente (ELNEZAMI et al., 2004).

A maioria dos ensaios de remoção de aflatoxinas dos trabalhos citados anteriormente foi realizada em soluções TFS. Shahin (2007) além de testar a habilidade de 27 cepas de Lactococcus spp. e 15 cepas de Streptococcus spp., isoladas de iogurte, leite cru e queijo Karish, em remover $\mathrm{AFB}_{1}$ em TFS, observando que Lactococcus lactis e Streptococcus thermophilus apresentaram os maiores 
níveis de remoção de toxina ( $54,85 \%$ e $81,0 \%$, respectivamente), também testou a habilidade de remoção de $\mathrm{AFB}_{1}$ das células viáveis e inviáveis em diferentes óleos vegetais, e observou que as células viáveis de $L$. lactis removeram de $71 \%$ a $86,7 \%$ da $\mathrm{AFB}_{1}$, enquanto que as células inviáveis removeram $100 \%$ da toxina em todos os óleos. Ainda, as células viáveis de $S$. thermophilus removeram de $66,5 \%$ a $91,5 \%$ da toxina, e as inviáveis de $81,7 \%$ a $96,8 \%$ da $A F B_{1}$.

Rasic et al. (1991) adicionaram $\mathrm{AFB}_{1}$ ao iogurte e leite acidificado, em concentrações de 1.000 e $1.400 \mu \mathrm{g} / \mathrm{Kg}$, obtendo a redução da $A F B_{1}$ no iogurte $(\mathrm{pH}$ 4,0) de $97,8 \%$ e $90 \%$, respectivamente, sendo que a diminuição máxima da $\mathrm{AFB}_{1}$ ocorreu durante a fermentação do leite. Para o leite acidificado com os ácidos cítrico, lático e acético $\left(\mathrm{pH} \mathrm{4,0)}\right.$ ), a redução da $\mathrm{AFB}_{1}$ (concentração de $1.000 \mu \mathrm{g} / \mathrm{Kg}$ ) foi de $90 \%, 84 \%$ e $73 \%$, respectivamente. Biernasiak et al. (2006) avaliaram a capacidade de bactérias probióticas (Lactobacillus paracasei, Lactobacillus casei, Lactobacillus brevis e Lactobacillus plantarum) e a levedura Saccharomyces cerevisiae em remover a soma das aflatoxinas $\left(B_{1}, B_{2}, G_{1}\right.$ e $\left.G_{2}\right)$ durante a fermentação de uma massa composta por $50 \%$ de farinha de cevada, $45 \%$ de farinha de trigo e $5 \%$ de farinha de milho, e observaram que após 6 horas de fermentação a quantidade de aflatoxina havia diminuído $18 \%$ e $33 \%$ para as massas adicionadas em 4 e $40 \mu \mathrm{g}$ de aflatoxina, respectivamente, e após 24 horas a quantidade de aflatoxina diminuiu em $27 \%$ e $50 \%$, respectivamente.

A polaridade das toxinas desempenha um papel importante nos mecanismos de ligação. $O$ percentual de aflatoxina removida pelas $B A L$ diminui na seguinte ordem: $\mathrm{AFB}_{1}>\mathrm{AFB}_{2}>\mathrm{AFG}_{1}>\mathrm{AFG}_{2}$, que está correlacionada com a diminuição da polaridade destas toxinas e é consistente com interações hidrofóbicas, as quais provavelmente também desempenham um papel no mecanismo de ligação (KABAK \& DOBSON, 2009). A AFM 1 também é removida de maneira menos eficaz que a $A F B_{1}$, entretanto, na literatura científica, ainda encontram-se poucos estudos sobre a capacidade das BAL em remover a AFM ${ }_{1}$.

Kabak \& Var (2008) examinaram a capacidade de 4 cepas de Lactobacillus spp. e 2 cepas de Bifidobacterium spp. em remover a AFM 1 em TFS e em leite desnatado reconstituído. Em solução TFS, as células viáveis das 6 cepas utilizadas foram capazes de remover de $10,22 \%$ a $26,65 \%$ da $A F M_{1}$ presente na solução, dependendo do nível de contaminação e do período de incubação, enquanto que as 
células inviáveis removeram de 14,04\% a 28,97\% da toxina. Em leite desnatado reconstituído com tempo de incubação de 4 horas, foram removidos 7,85\% a 25,94\% da $A F M_{1}$ pelas células viáveis e $12,85 \%$ a $27,31 \%$ pelas células inviabilizadas termicamente. Pierides et al. (2000), compararam a atividade de remoção de AFM $_{1}$ em TFS $(50,7 \%)$ com a remoção de $A_{F} B_{1}$ na mesma solução $(75,3 \%)$ por $L$. rhamnosus GG, e concluíram que a remoção da primeira micotoxina foi menos efetiva possivelmente devido à presença de um grupo $-\mathrm{OH}$ adicional na molécula de $\mathrm{AFM}_{1}$ resultando em um aumento de polaridade, o que a torna mais hidrofílica e aumenta sua tendência em ficar retida em soluções aquosas.

Alguns tratamentos físicos, químicos e enzimáticos podem aumentar a habilidade das BAL em unir-se à aflatoxina do meio. A aplicação de ácido clorídrico e tratamento térmico em autoclave ou fervura a $100{ }^{\circ} \mathrm{C}$ sobre L. rhamnosus GG e LC705 causaram aumento significativo na remoção da $\mathrm{AFB}_{1}$, verificando-se que a degradação metabólica por parte das células viáveis das bactérias pode ser descartada como possível mecanismo de atuação (EL-NEZAMI et al., 1998a; ELNEZAMI et al., 1998b).

Comparando-se a habilidade de células viáveis e tratadas termicamente de bifidobactérias, chegou-se ao resultado de que as células viáveis removeram de $4 \%$ a $56 \%$ da $\mathrm{AFB}_{1}$ do meio, enquanto as células inviáveis de $12 \%$ a $82 \%$ (PELTONEM et al., 2001). Azab et al. (2005) avaliando a influência de tratamentos de inativação sob a capacidade de 4 tipos de Lactobacillus spp. em remover a AFB ${ }_{1}$, observaram que os tratamentos ácido $(58,6 \%$ a $87,0 \%)$ e térmico $(33,5 \%$ a $71,9 \%)$ aumentaram a capacidade de remoção quando comparados à solução TFS (16,3\% a 56,6\%), enquanto que os tratamentos alcalino (8,3\% a $27,4 \%)$ e com etanol $(15,9 \%$ a $46,5 \%)$ diminuíram a quantidade de aflatoxina removida.

Percebe-se que ambas as células, viáveis e inviáveis, conseguem remover a aflatoxina em soluções aquosas. Pelo fato de as células inviáveis conseguirem também realizar essa remoção da toxina, supõe-se que ocorra uma união de natura física com a mesma, ou seja, uma adesão aos componentes da parede celular bacteriana, principalmente aos polissacarídeos e aos peptidoglicanos, ao invés de ocorrer através de ligação covalente ou degradação pelo metabolismo da bactéria (BATA \& LASZTITY, 1999; LAHTINEN et al., 2004; SHETTY \& JESPERSEN, 2006). 
Entretanto, não apenas o tipo de cepa bacteriana e a viabilidade das células podem influenciar sobre a formação e a estabilidade do complexo BAL/aflatoxina, mas também muitos outros fatores como a concentração bacteriana, a especificidade da bactéria, o pH, a temperatura de incubação, a adição de nutrientes, os solventes utilizados e outros. Deve-se levar em consideração que a estabilidade do complexo BAL/aflatoxina formado é crítica para uma implementação segura desse método de descontaminação.

Assim, abrem-se perspectivas de utilização das BAL para redução da biodisponibilidade de micotoxinas em alimentos contaminados, seja através da incorporação de uma bactéria específica diretamente no alimento, seja pela inoculação de bactérias em animais desde seu nascimento. $O$ desenvolvimento de um método seguro, barato e que exija baixa tecnologia, desvendando-se todos os efeitos sobre as matrizes alimentícias e sobre os animais, trará inúmeros benefícios, especialmente para os países em desenvolvimento, onde os esforços para combater a contaminação dos alimentos são geralmente limitados pela falta de recursos e tecnologia. O resultado será a melhora da qualidade e segurança dos alimentos e da produção animal, trazendo, consequentemente, benefícios para a saúde humana. 


\section{Metodologia}

\subsection{Bactérias, condições de cultivo e estimativa da concentração bacteriana}

As bactérias ácido-láticas utilizadas no presente projeto foram originadas de cepas previamente certificadas, pertencentes aos gêneros Lactobacillus, Pediococcus, Enterococcus e Bifidobacterium. Os isolados de BAL, identificados na Tabela 3 com os números 1, 2 e 3, foram provenientes da coleção de culturas lácteas do TECNOLAT - Centro de Pesquisa e Desenvolvimento de Laticínios do Instituto de Tecnologia de Alimentos (ITAL) de Campinas/SP. Os isolados identificados com os números 4,5 e 6 foram doados gentilmente pela empresa Danisco Brasil Ltda., enquanto que a cepa de número 7 foi obtida na Fundação Tropical de Pesquisas e Tecnologia André Tosello localizada em Campinas/SP.

Tabela 3 - Cepas bacterianas utilizadas nos ensaios de remoção da AFM 1 .

\begin{tabular}{ccc}
\hline Número & Cepa & Bactéria \\
\hline 1 & CTC 368 & Lactobacillus plantarum \\
2 & CTC 469 & Enterococcus avium \\
3 & TR 570 & Pediococcus pentosaceus \\
4 & LB 340 LYO 2 DCU & Lactobacillus delbrueckii spp. bulgaricus \\
5 & HOWARU® LYO 40 DCU & Lactobacillus rhamnosus \\
6 & FLORA-FIT BI 07 & Bifidobacterium lactis \\
7 & ATCC 33323 & Lactobacillus gasseri \\
\hline
\end{tabular}

As cepas bacterianas foram recebidas na forma liofilizada, sendo reativadas em caldo MRS - Man, Rogosa \& Sharpe (Acumedia $\AA^{\circledR}$ - Lansing, MI, USA) a $37^{\circ} \mathrm{C}$ e conservadas sob temperatura de congelamento de $-80^{\circ} \mathrm{C}$ em tubos de $2 \mathrm{~mL}$, onde eram adicionados $800 \mu \mathrm{L}$ da cultura bacteriana crescida em caldo MRS e $200 \mu \mathrm{L}$ de 
glicerol estéril (Synth® - Diadema, SP, Brasil), tendo este a função de agente crioprotetor.

Para a reativação das cepas, estas foram descongeladas rapidamente, sendo repicadas em caldo MRS e incubadas a temperatura de $37^{\circ} \mathrm{C}$ por 48 horas. As culturas foram repicadas em caldo MRS repetidas vezes até que as mesmas alcançassem uma concentração elevada de células. Sempre que as cepas bacterianas eram reativadas, sua pureza era examinada através de plaqueamento em profundidade em ágar MRS (Acumedia® - Lansing, Michigan, USA) para verificação das colônias formadas e também por coloração de Gram.

O plaqueamento em profundidade foi realizado em duplicata, seguindo-se 0 procedimento sugerido pela APHA (2004) (Figura 3). Nesse procedimento, após a diluição seriada da cultura bacteriana, inoculou-se $1 \mathrm{~mL}$ de cada diluição em placas de Petri estéreis vazias, adicionando-se, em seguida, o meio de cultura (ágar MRS), sendo que para garantir as condições microaerófilas, as placas foram acondicionadas invertidas em uma câmara de anaerobiose contendo um gerador de anaerobiose (Probac do Brasil - São Paulo, SP, Brasil) e, então, incubadas a temperatura de $37 \pm 1^{\circ} \mathrm{C}$ por $48 \pm 3$ horas. Foram selecionadas para contagem as placas com 25 a 250 colônias, sendo o cálculo do resultado feito de acordo com o número de colônias confirmadas e a diluição inoculada. Os resultados foram expressos em unidades formadoras de colônia (UFC) por $\mathrm{mL}$ de meio.

A estimativa da concentração de cada cepa bacteriana nos caldos preparados foi determinada através da técnica de Turbidimetria, método que analisa o crescimento bacteriano em tempo real através de medidas de densidade óptica. Após o crescimento da cultura de bactérias em caldo MRS por 24 horas a $37^{\circ} \mathrm{C}$, foi criada uma curva de concentração correlacionando-se a medida da absorbância (em duplicata) encontrada em espectrofotômetro Spectrumlab 22PC (Shanghai Lengguang Technology Co. Ltd - Shanghai, China) a $600 \mathrm{~nm}$ para cada diluição seriada realizada no próprio caldo MRS (diluído em 10 vezes) com o logaritmo da concentração bacteriana obtida através da contagem de colônias por plaqueamento em profundidade (BEGOT et al., 1996). 


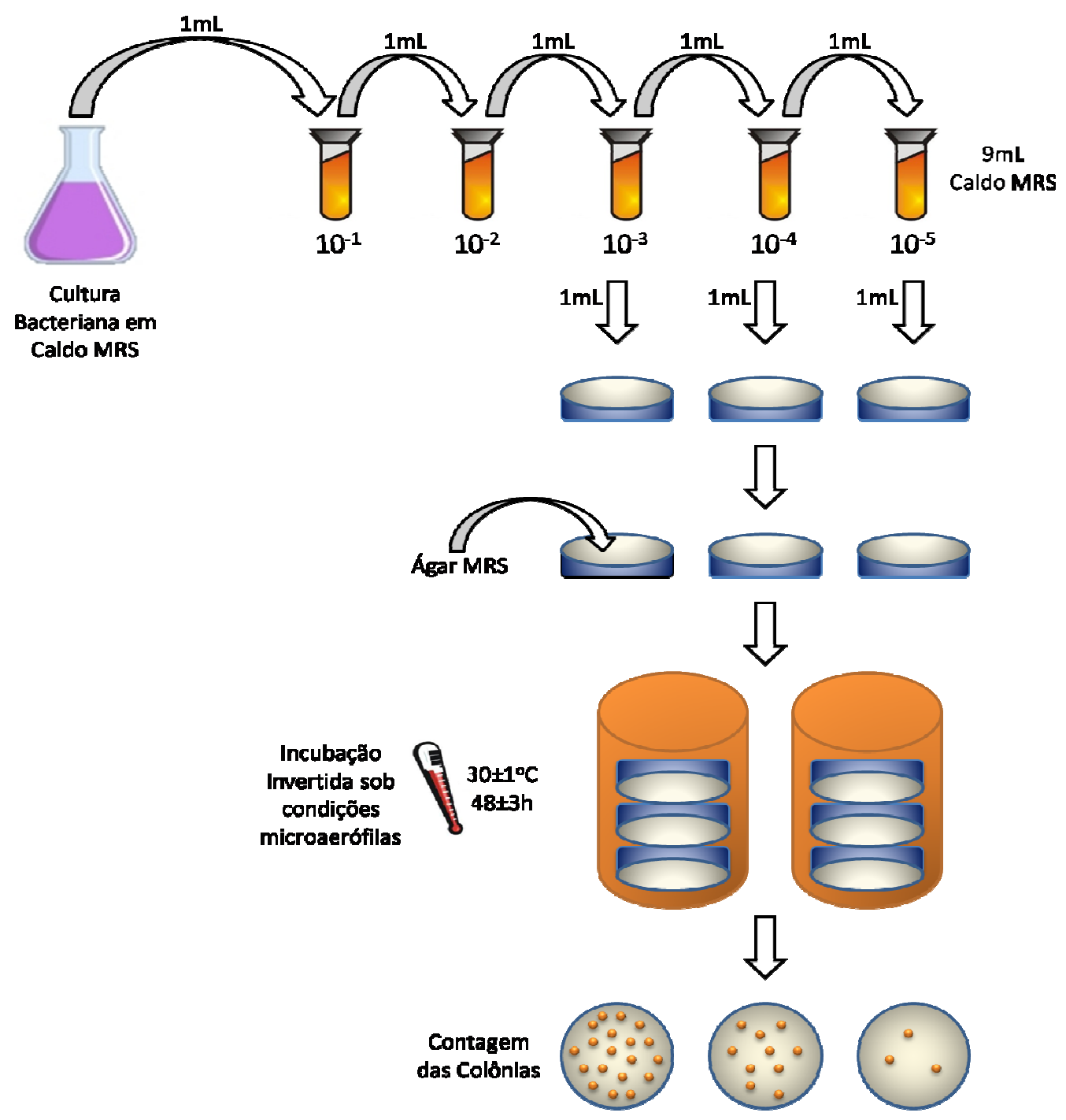

Figura 3 - Fluxograma das análises para contagem de BAL.

\subsection{Ensaio de remoção da aflatoxina $\mathbf{M}_{1}$ em solução TFS}

Foi utilizado padrão de $\mathrm{AFM}_{1}$ (Supelco ${ }^{\mathrm{TM}}$ - Bellefonte, PA, USA), dissolvido em acetonitrila, o qual foi calibrado espectrofotometricamente através da técnica preconizada por Scott (1990) e diluído de maneira a obter uma solução estoque contendo aproximadamente $3,0 \mu \mathrm{g} \mathrm{AFM} / \mathrm{mL}$. Esta solução foi utilizada no preparo de outra solução de trabalho contendo cerca de $0,15 \mu \mathrm{g} \mathrm{AFM} / \mathrm{mL}$ em TFS $(\mathrm{pH} 7,3)$ (Laborclin Ltda., Pinhais, PR, Brasil), sendo a acetonitrila completamente evaporada por injeção direta de nitrogênio e aquecimento em banho a $45^{\circ} \mathrm{C}$ antes da adição do TFS. 
A realização do experimento foi conduzida adaptando-se o método utilizado por Pierides et al. (2000). Após a incubação de cada cepa bacteriana em caldo MRS a $37^{\circ} \mathrm{C}$ por 24 horas, fez-se a imersão do tubo em banho contendo água e gelo por 3 minutos a fim de parar o crescimento das bactérias e realizou-se a leitura em espectrofotômetro para determinação da concentração de células bacterianas no meio através da curva de calibração construída previamente. Em seguida, um volume do caldo com a cultura de bactérias correspondendo a cerca de $1 \times 10^{10}$ células foi centrifugado (Microcentrífuga CT-14000, Cientec - Piracicaba, SP, Brasil) a 4.000 rpm por 15 minutos para a formação de pellets das bactérias. Os pellets formados foram lavados com água Milli-Q (Simplicity 185, Millipore $\AA$ - Billerica, MA, USA) estéril e, então, ressuspensos em $1,5 \mathrm{~mL}$ da solução TFS contendo a aflatoxina. As soluções de bactérias e aflatoxina foram incubadas pelos tempos de 15 minutos e 24 horas a $37^{\circ} \mathrm{C}$.

Após o término dos tempos de incubação, as células foram novamente centrifugadas a $4.000 \mathrm{rpm}$ por 15 minutos e o sobrenadante obtido foi analisado através da técnica de cromatografia líquida de alta eficiência (CLAE). Seguidamente à retirada do sobrenadante, foi realizada uma lavagem dos pellets restantes com solução TFS sem a aflatoxina (adição de 1,5 mL de TFS e agitação em vortex por 20 segundos) e nova centrifugação sob as mesmas condições descritas anteriormente, sendo o sobrenadante obtido também analisado por CLAE. Para cada tipo de bactéria, um controle negativo (células bacterianas suspensas em TFS), um controle positivo ( $A F M_{1}$ em TFS) e também um controle neutro (apenas TFS) foram incubados e analisados.

Também foram feitas análises das células bacterianas inviáveis. Após a etapa de incubação em caldo MRS a $37^{\circ} \mathrm{C}$ por 24 horas e medição espectrofotométrica da concentração de bactérias, a cultura bacteriana ficou em água fervente $\left(100^{\circ} \mathrm{C}\right)$ por 1 hora para inviabilização das células. Em seguida, foram realizadas as mesmas etapas descritas acima a partir do recolhimento de um volume de caldo com a cultura de bactérias correspondendo a cerca de $1 \times 10^{10}$ células. $O$ fluxograma dos ensaios de união de $A F M_{1}$ e BAL em solução TFS para as bactérias viáveis e inviáveis encontra-se na Figura 4. 


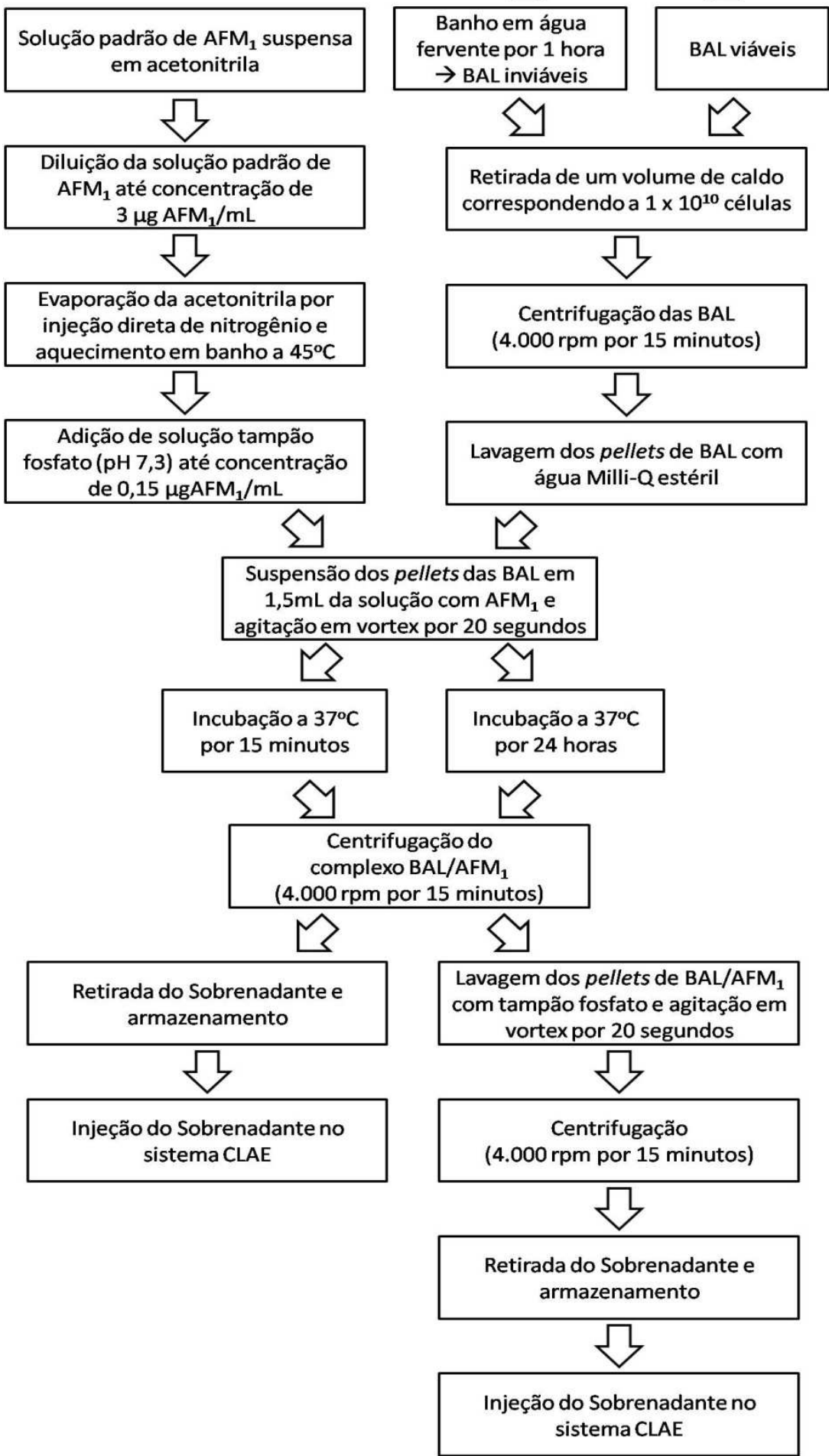

Cultivo das BAL em caldo MRS a $37^{\circ} \mathrm{C}$ por 24 horas

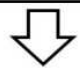

Leitura em espectrofotômetro para determinação da concentração bacteriana concentraçãobacteriana

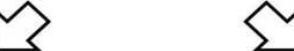

nho em água

rvente por 1 hor

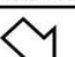

Retirada de um volume de caldo correspondendo a $1 \times 10^{10}$ células

Centrifugação das BAL

minutos)

Lavagem dos pellets de BAL com água Milli-Q estéril

uspensão dos pellets das BAL em

$15 \mathrm{~mL}$ da solução com AFM 1

Incubação a $37^{\circ} \mathrm{C}$

cubação a $37^{\circ} \mathrm{C}$

Centrifugação do complexo BAL/AFM

$000 \mathrm{rpm}$ por 15 minutos)

Lavagem dos pellets de BAL/AFM

m tampão fosfato e agitação em expor 20 segundos

Centrifugação

$4.000 \mathrm{rpm}$ por 15 minutos)

Retirada do Sobrenadante armazenamento

Injeção do Sobrenadante no sistema CLAE

Figura 4 - Fluxograma dos ensaios de remoção de $\mathrm{AFM}_{1}$ pelas BAL em TFS. 


\subsection{Quantificação da Aflatoxina $M_{1}$ em TFS através de CLAE}

Para a quantificação da $A F M_{1}$ em solução TFS utilizando o sistema CLAE, não foi necessária a realização de procedimentos de purificação do sobrenadante. Assim, este foi injetado diretamente no sistema CLAE (Shimadzu® - Tóquio, Japão) constituído de detector de fluorescência RF-10A XL (Shimadzu ${ }^{\circledR}$ ), equipado com coluna Sinergy Fusion $4 \mu \mathrm{m} \mathrm{C}_{18} 4,6$ X $150 \mathrm{~mm}$ (Phenomenex® - Torrance, CA, USA) e amostrador automático SIL-10AF (Shimadzu®), sendo que o sistema foi estabilizado por uma hora a um fluxo de $1 \mathrm{~mL} / \mathrm{min}$ à temperatura ambiente. A fase móvel utilizada foi uma solução de água, acetonitrila e metanol na proporção de 60:20:20, com um fluxo de $1 \mathrm{~mL} / \mathrm{min}$. A detecção da excitação foi feita a um comprimento de onda de $366 \mathrm{~nm}$ e a emissão a $428 \mathrm{~nm}$.

A quantificação do percentual de $\mathrm{AFM}_{1}$ adsorvida pela bactéria foi feita através da Equação 1. Após a análise dos resultados, foram selecionadas para os ensaios previstos no item 3.4 três cepas de BAL que apresentaram os melhores resultados de eficiência de redução (> 33\%) da concentração de $A_{F} M_{1}$ na solução TFS.

$$
A=\left\{\frac{[(B-C)-(D-E)]}{B-C}\right\} * 100 \quad \text { Equação } 1
$$

Onde,
A: percentual de $\mathrm{AFM}_{1}$ adsorvida pela bactéria
$B$ : área do pico cromatográfico do controle positivo ( $A F M_{1}$ em solução TFS)
$\mathrm{C}$ : área do pico cromatográfico do controle neutro (somente solução TFS)
D: área do pico cromatográfico da amostra (AFM 1 em solução TFS + cepa BAL)
E: área do pico cromatográfico do controle negativo (solução TFS + cepa BAL) 


\subsection{Ensaio de remoção da aflatoxina $M_{1}$ pelas BAL mais eficientes em leite UHT desnatado}

As três cepas de BAL selecionadas conforme o critério descrito anteriormente foram submetidas novamente aos mesmos procedimentos descritos no item 3.2, porém utilizando-se como meio para os ensaios, ao invés da solução TFS, o leite UHT desnatado ultra-fresh (leite que passou pelo processo de bactofugação, o qual é utilizado para eliminar bactérias contidas no leite mediante o emprego de força centrífuga) da marca Shefa $\AA^{\circledR}$, lote V2770209 (fabricação em 04/10/2010. Além da mudança do meio, foram utilizadas duas diferentes condições de temperatura $\left(4^{\circ} \mathrm{C} \mathrm{e}\right.$ $37^{\circ} \mathrm{C}$ ) e apenas um tempo de incubação de 15 minutos, sendo que, após a retirada do sobrenadante para análise por CLAE, os pellets de BAL restantes não passaram pelo processo de lavagem.

Todas as BAL foram inviabilizadas através de banho em água fervente por 1 hora a fim de evitar uma possível fermentação do leite durante o período de incubação. Para esse ensaio de remoção em leite, a quantidade de $\mathrm{AFM}_{1}$ adicionada ao leite UHT desnatado ultra-fresh foi menor quando comparada ao ensaio em TFS (aproximadamente $0,5 \mu \mathrm{g} \mathrm{AFM} /$ /litro de leite), sendo esse valor escolhido baseandose no limite máximo permitido para a $A_{F M}$ em leite fluido $(0,5 \mu \mathrm{g} / \mathrm{L})$ imposto pela legislação brasileira (BRASIL, 2002).

No caso do leite, o sobrenadante retirado após a centrifugação do complexo BAL/AFM 1 passou por um processo de purificação da $A_{F} M_{1}$ em uma coluna de imunoafinidade NeoColumn ${ }^{\circledR}$ (Neogen Europe Ltd. - Scotland, UK), para a retirada de impurezas contidas no mesmo. A coluna de imunoafinidade foi acoplada a um manifold, que por sua vez estava ligado a uma bomba de vácuo (Modelo 131 Tipo $2 \mathrm{~V}$, Prismatec - Itu, SP, Brasil) (Figura 5). Primeiramente, passou-se pela coluna 0,5 $\mathrm{mL}$ de TFS e depois $1,0 \mathrm{~mL}$ do sobrenadante a ser analisado a um fluxo de 2 a 3 gotas por segundo. Em seguida, lavou-se a coluna através da passagem de $20 \mathrm{~mL}$ de uma solução de metanol:água (25:75) e eluiu-se a toxina passando-se $1 \mathrm{~mL}$ de uma solução de metanol:ácido acético (98:2) e $1 \mathrm{~mL}$ de água Milli-Q a um fluxo, recolhendo-se os $2 \mathrm{~mL}$ finais em um vial (Figura 6). 
A corrida cromatográfica e a quantificação da $A F M_{1}$ procederam-se nas mesmas condições descritas anteriormente no item 3.3. Para cada tipo de bactéria, também foram incubados e analisados um controle positivo ( $A_{F} M_{1}$ em leite), um controle negativo (leite com a presença das células bacterianas) e um controle neutro (leite sem a presença das células bacterianas). A Figura 7 apresenta um resumo das etapas dos ensaios de união de $A F M_{1}$ e $B A L$ nos leites experimentais.

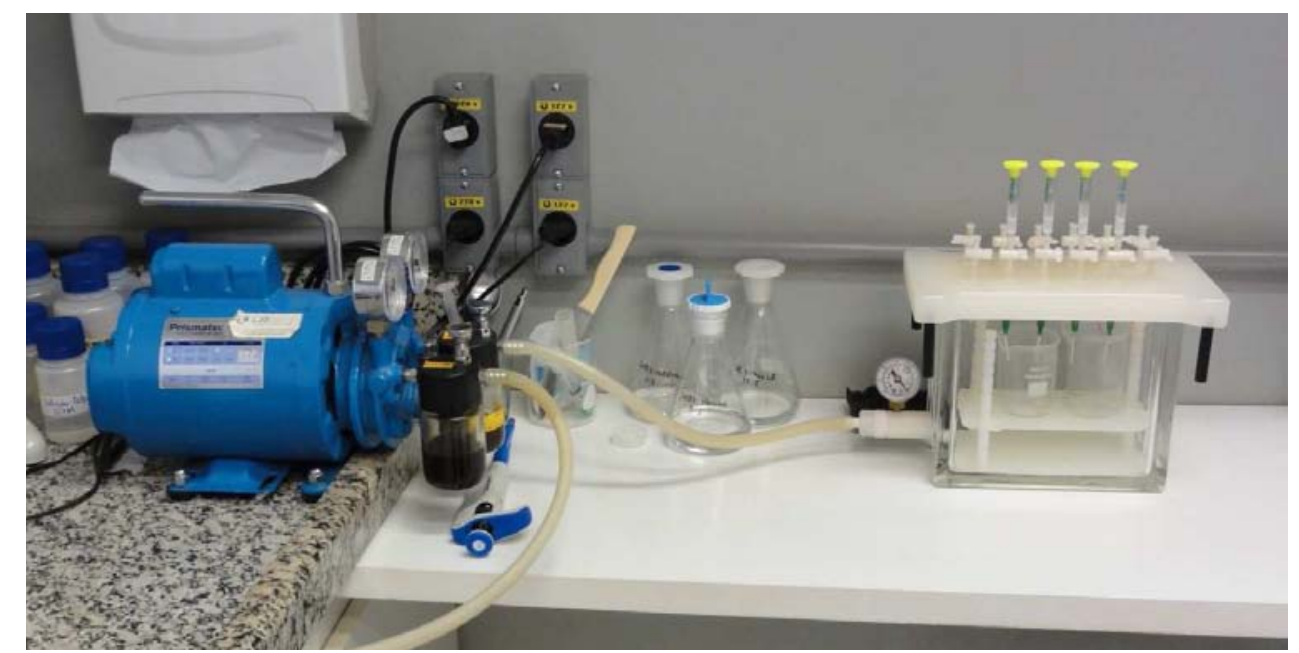

Figura 5 - Colunas de imunoafinidade acopladas a um manifold e bomba de vácuo.

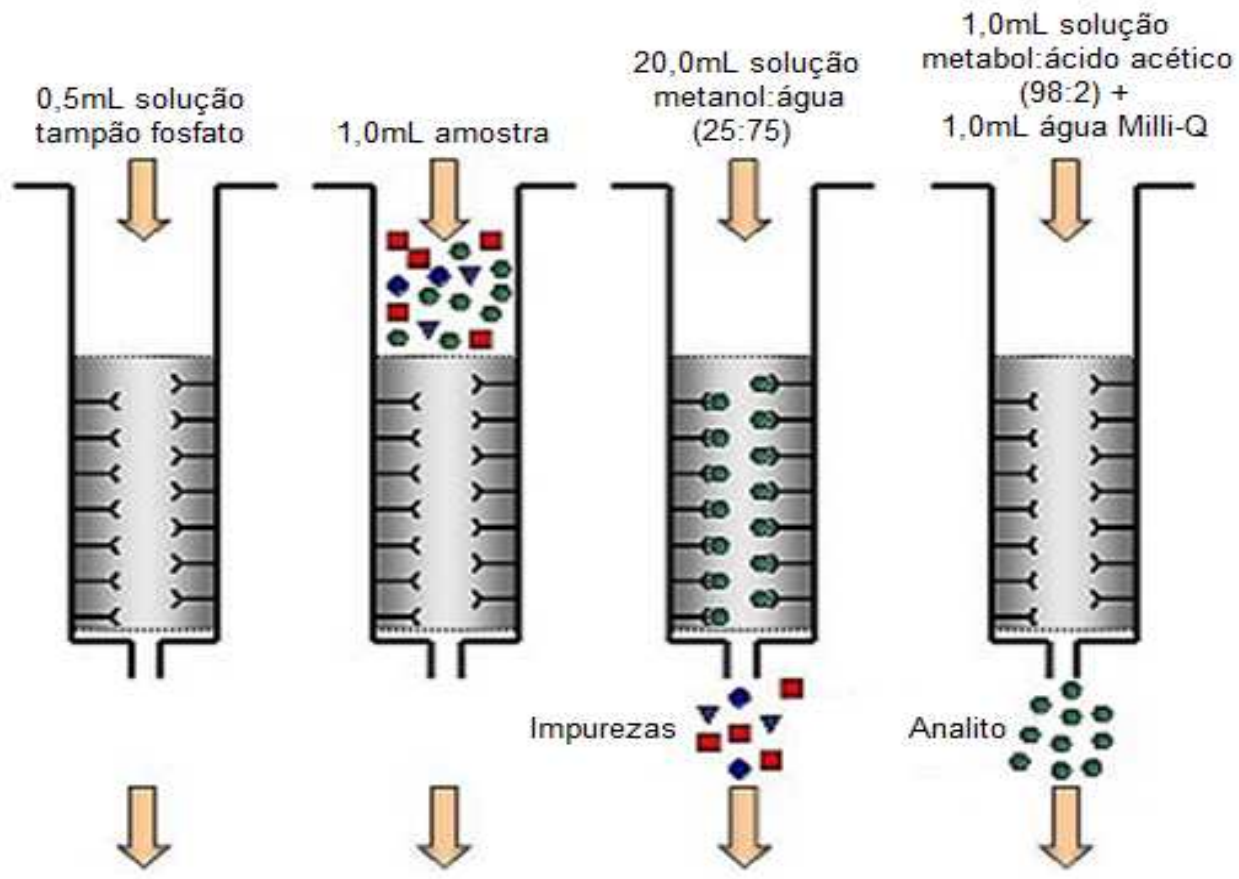

Figura 6 - Processo de eluição da $\mathrm{AFM}_{1}$ em coluna de imunoafinidade. 


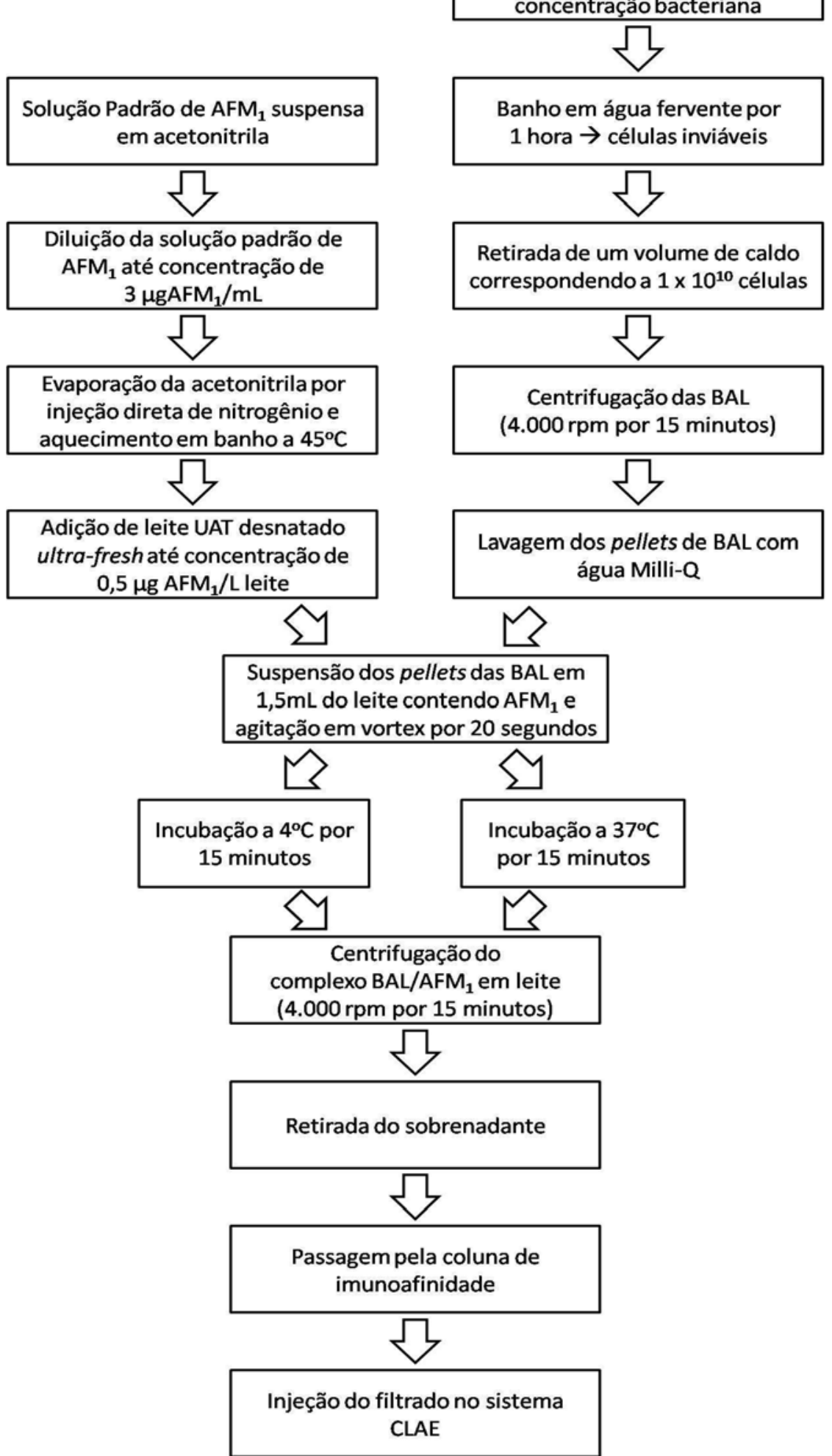

BAL com melhor eficiência de remoção da $\mathrm{AFM}_{1}$ cultivada a $37^{\circ} \mathrm{C}$ por 24 horas em caldo MRS

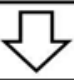

Leitura em espectrofotômetro para determinação da concentração bacteriana

Retirada de um volume de caldo correspondendo a $1 \times 10^{10}$ células até concentração de $\mathrm{FM}_{1} / \mathrm{mL}$ 


\subsection{Análise dos resultados}

Os resultados obtidos foram submetidos à análise de variância, de acordo com os procedimentos estabelecidos no General Linear Model do SAS ${ }^{\circledR}$ (SAS Institute, 1992), para a verificação de diferenças estatisticamente significativas entre os percentuais de redução de $A F M_{1}$ pelas cepas de BAL na solução TFS e no leite. Para a comparação entre as médias, quando aplicável, empregou-se o teste de Tukey, adotando-se, como nível de rejeição, $\alpha=0,05$ (GACULA \& SINGH, 1984). 


\section{Resultados e Discussão}

\subsection{Curva de concentração bacteriana}

As curvas de concentração bacteriana, apresentadas na Figura 8, foram construídas através da correlação entre as medidas de absorbância obtidas e do plaqueamento em profundidade de cada bactéria. Pode-se observar, na Figura 9, um exemplo de uma placa de Petri com colônias típicas de BAL, mais precisamente Lactobacillus plantarum resultantes do plaqueamento em profundidade realizado para determinar a concentração bacteriana no caldo MRS cultivado por 24 horas a $37^{\circ} \mathrm{C}$.

A partir dos dados obtidos, geraram-se equações potenciais, que foram utilizadas para o cálculo da concentração bacteriana no meio e, em seguida, para o cálculo do volume de meio com o cultivo de bactérias utilizado para alcançar uma concentração de células de cerca de 1,0 × 10 ${ }^{10}$ UFC. Observa-se que esse tipo de equação adequou-se perfeitamente aos dados, já que o valor do coeficiente de determinação $\left(R^{2}\right)$ de cada uma das equações variou entre 0,997 e 0,999. A Tabela 4 apresenta as equações e os valores dos coeficientes de determinação obtidos para cada bactéria, assim como a concentração bacteriana no meio.

Tabela 4 - Valores de absorbância e concentração bacteriana.

\begin{tabular}{cccc}
\hline Bactéria & Equação & $\begin{array}{c}\text { Coeficiente de } \\
\text { Determinação }\left(\mathbf{R}^{2}\right)\end{array}$ & $\begin{array}{c}\text { Contagem Média } \\
(\mathbf{U F C} / \mathbf{m L})\end{array}$ \\
\hline L. plantarum & $\mathrm{Y}=9,055 * \mathrm{X}^{0,048}$ & 0,998 & $4,35 \times 10^{9}$ \\
E. avium & $\mathrm{Y}=8,888 * \mathrm{X}^{0,050}$ & 0,997 & $2,05 \times 10^{9}$ \\
P. pentosaceus & $\mathrm{Y}=9,137 * \mathrm{X}^{0,057}$ & 0,999 & $9,20 \times 10^{9}$ \\
L. bulgaricus & $\mathrm{Y}=8,047 \times \mathrm{X}^{0,072}$ & 0,997 & $1,17 \times 10^{9}$ \\
L. rhamnosus & $\mathrm{Y}=8,353 * \mathrm{X}^{0,069}$ & 0,998 & $1,94 \times 10^{9}$ \\
B. lactis & $\mathrm{Y}=8,420 * \mathrm{X}^{0,047}$ & 0,998 & $1,21 \times 10^{9}$ \\
L. gasseri & $\mathrm{Y}=8,080 * \mathrm{X}^{0,058}$ & 0,999 & $6,60 \times 10^{8}$ \\
\hline
\end{tabular}




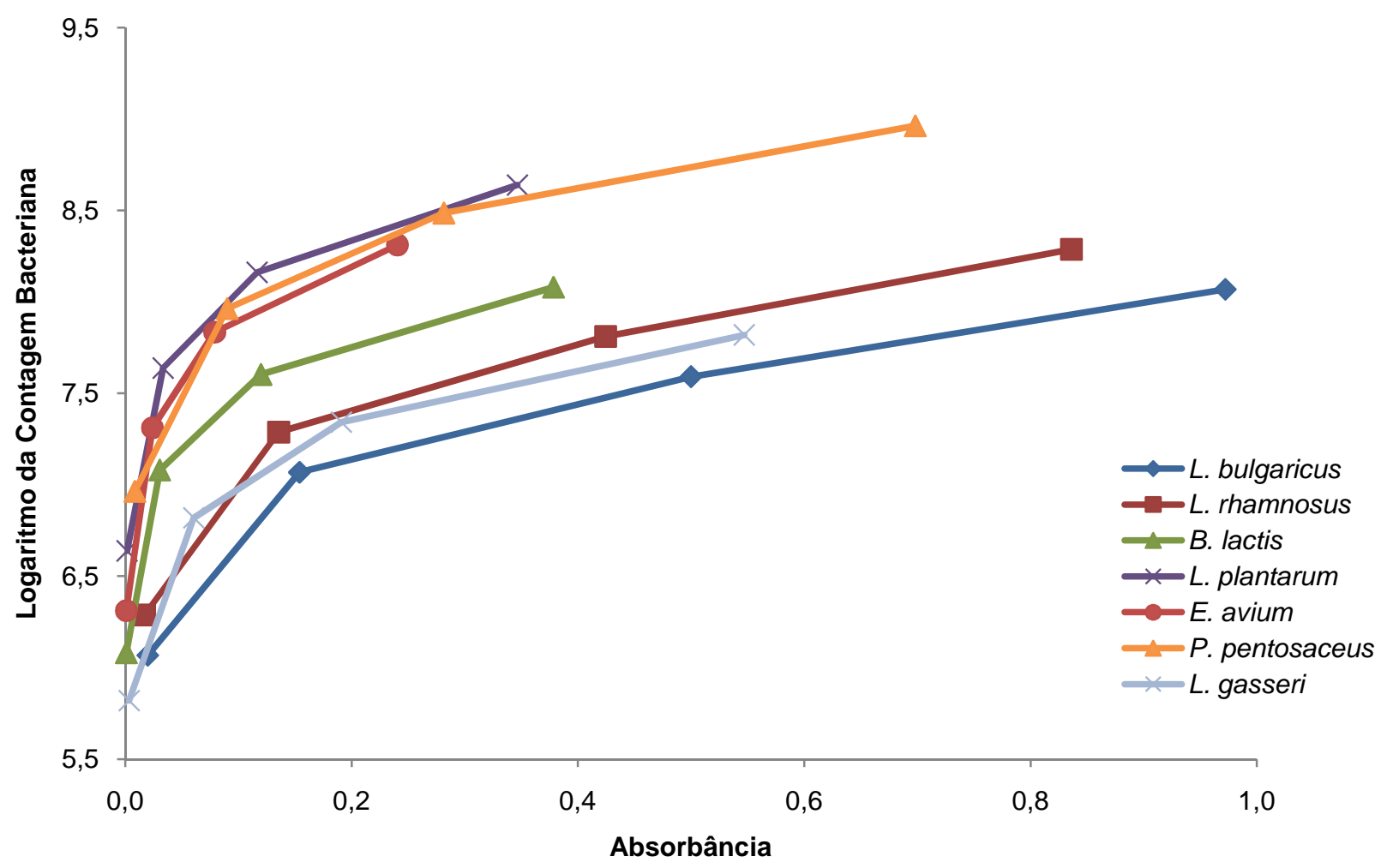

Figura 8 - Curvas de concentração bacteriana para as sete cepas de BAL.

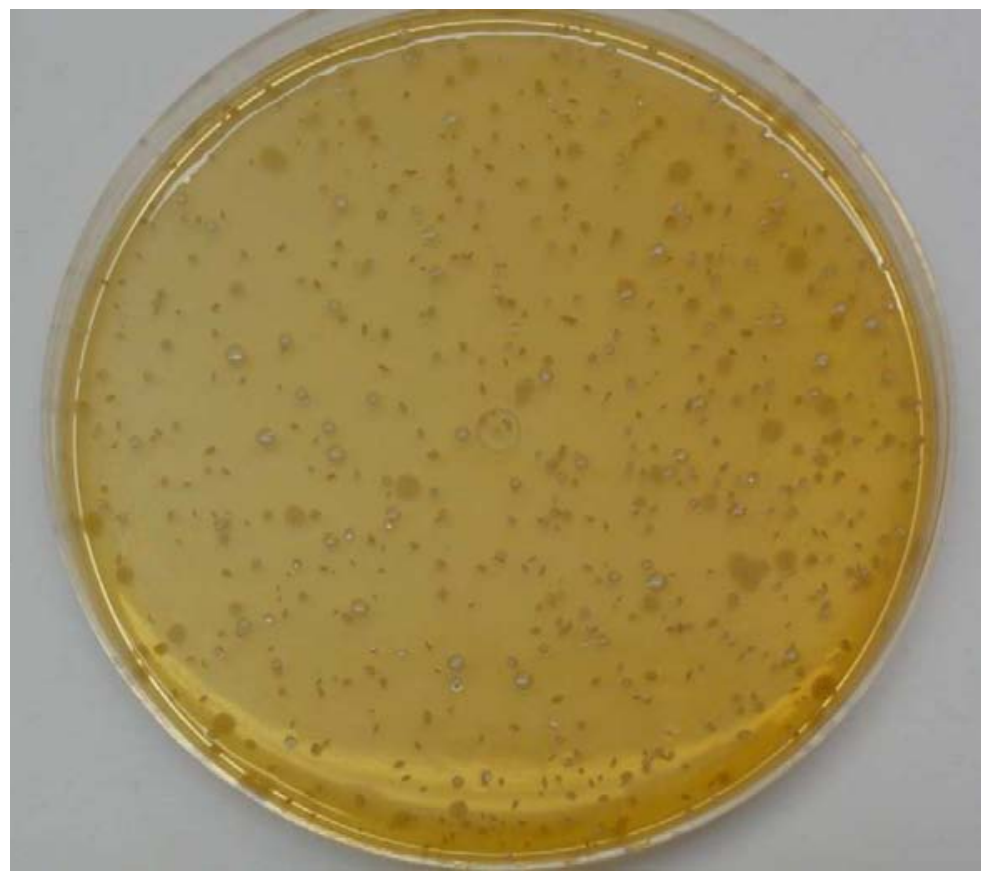

Figura 9 - Placa de Petri com colônias típicas de Lactobacillus plantarum. 


\subsection{Remoção da $A F M_{1}$ em solução TFS}

Conforme explicado no item 3.2, foram obtidas as porcentagens de remoção de $\mathrm{AFM}_{1}$ pelas $\mathrm{BAL}$, comparando-se os cromatogramas gerados pelo sistema CLAE, tanto para as células bacterianas viáveis quanto para as inviáveis à temperatura de $37^{\circ} \mathrm{C}$ nos tempos de contato de 15 minutos e 24 horas. Observa-se nas Figuras 10, 11 e 12 exemplos desses cromatogramas para um controle positivo, para uma amostra de células viáveis de Lactobacillus plantarum no tempo de contato de 15 minutos e para uma amostra de células inviáveis de Enterococcus avium no tempo de 15 minutos, respectivamente. O tempo de retenção da $A F M_{1}$ nas condições de análise especificadas no item 3.3 foi de 6,1 minutos. Os resultados encontrados para os ensaios de remoção estão descritos na Tabela 5.

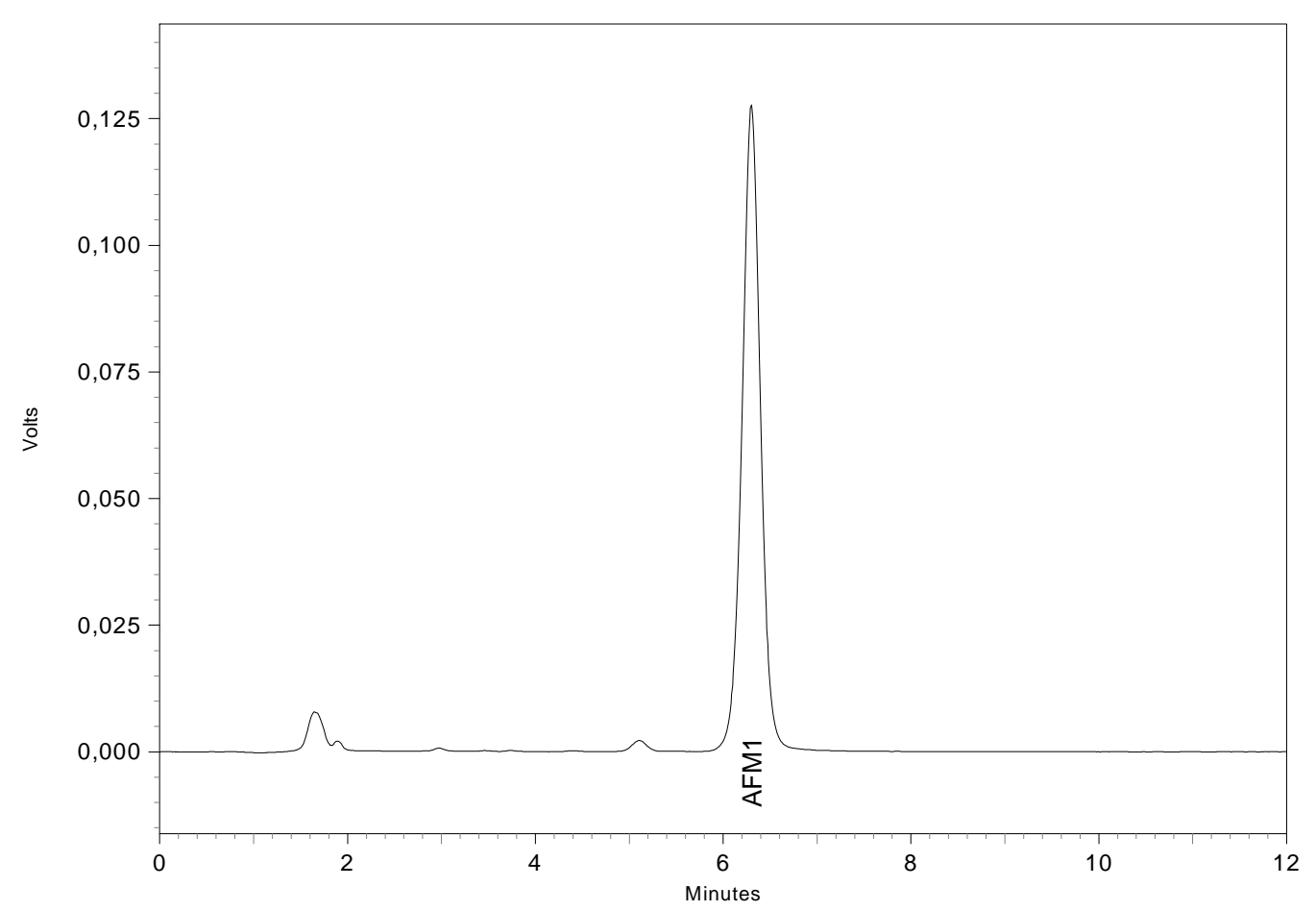

Figura 10 - Cromatograma do controle positivo. 


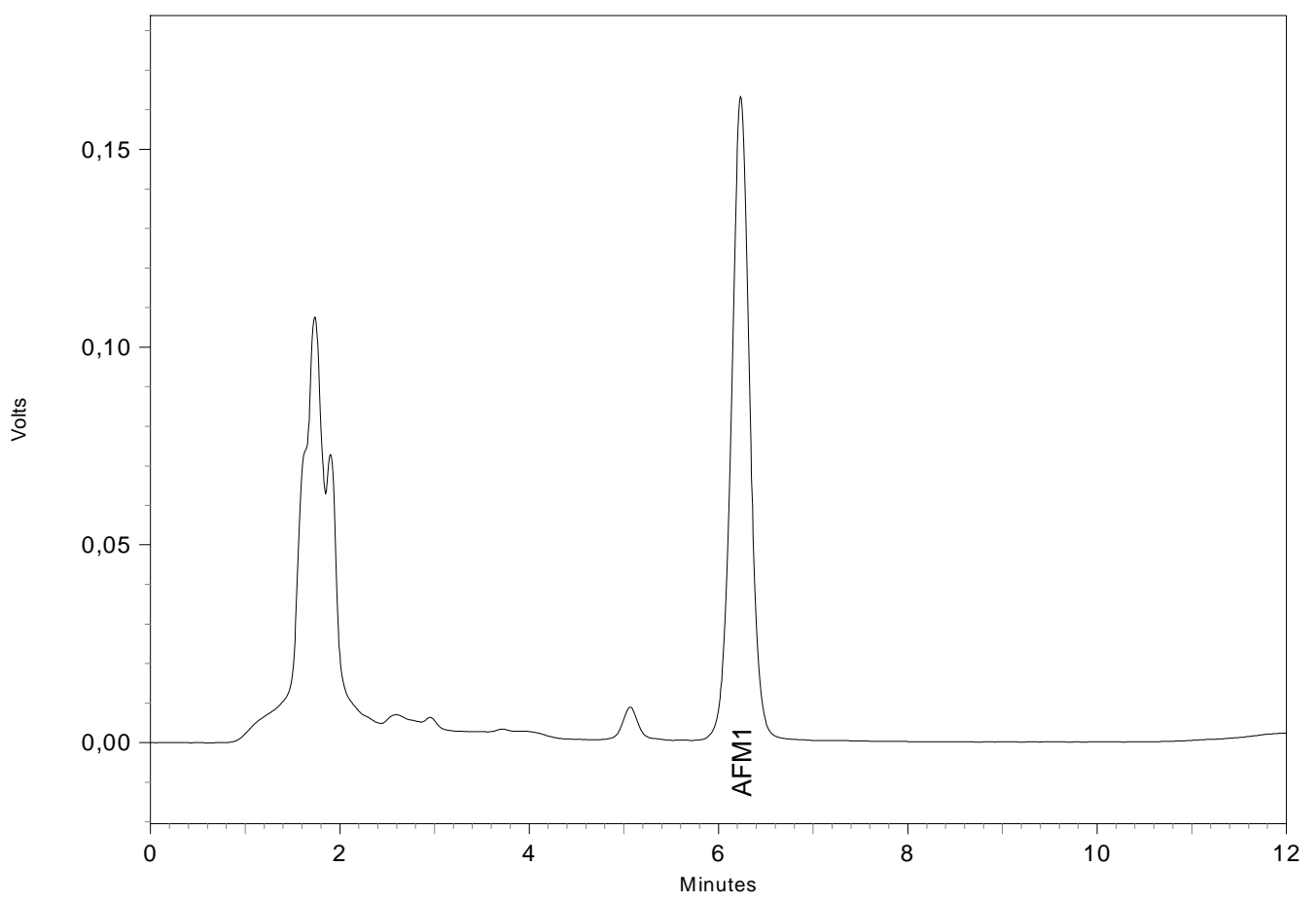

Figura 11 - Cromatograma de uma amostra de células viáveis de Lactobacillus plantarum no tempo de contato de 15 minutos.

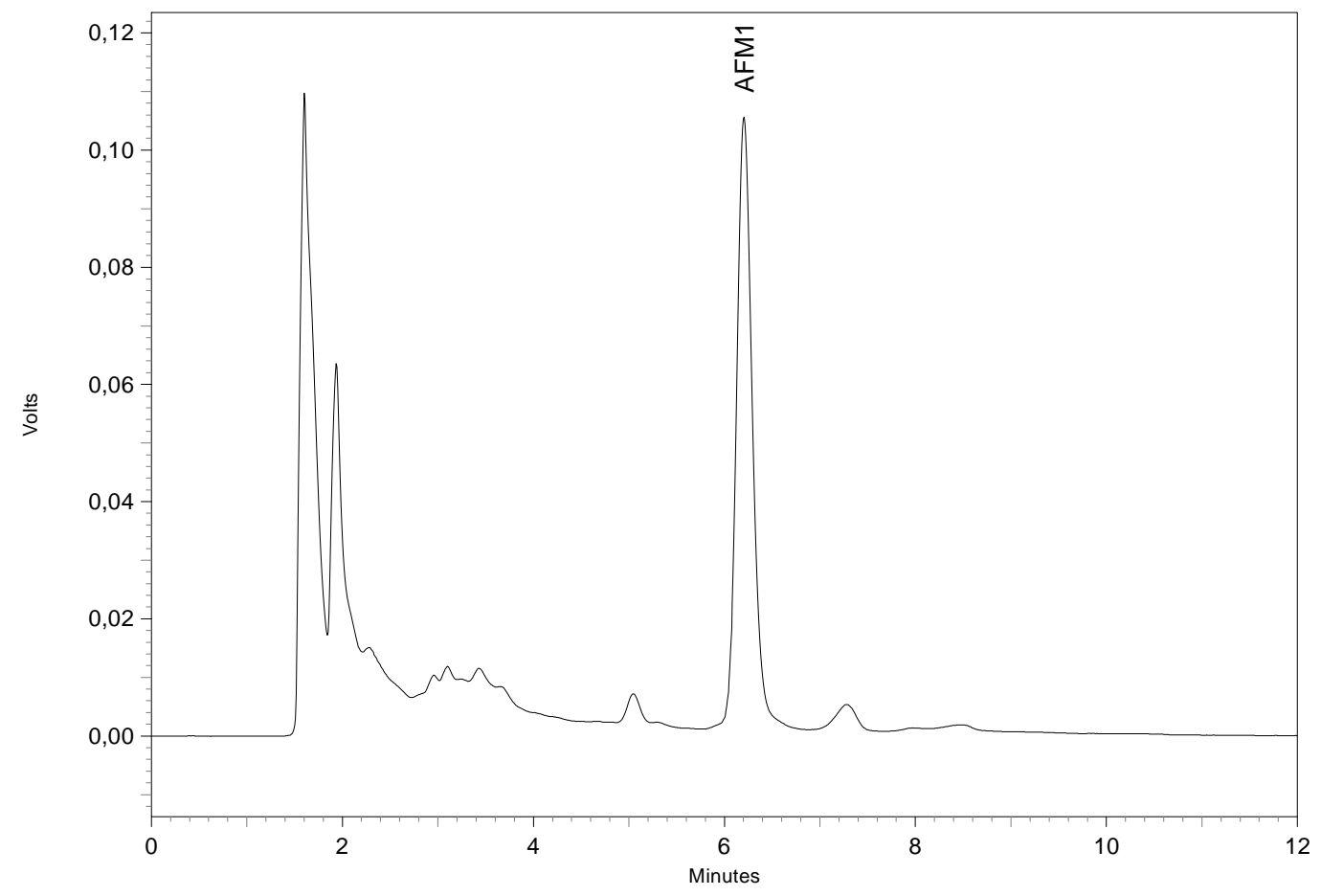

Figura 12 - Cromatograma de uma amostra de células inviáveis de Enterococcus avium no tempo de contato de 15 minutos. 
Tabela 5 - Percentual de remoção ${ }^{1}$ de AFM $_{1}$ em solução TFS ${ }^{2}$.

\begin{tabular}{|c|c|c|c|c|}
\hline \multirow{2}{*}{ Bactérias } & \multicolumn{4}{|c|}{ \% de Remoção de AFM 1} \\
\hline & Viável 15min ${ }^{3}$ & Inviável 15min & Viável 24h & Inviável 24h \\
\hline L. plantarum & $5,60 \pm 0,45^{\mathrm{CB}}$ & $13,11 \pm 0,89^{\mathrm{bA}}$ & $8,09 \pm 1,33^{\mathrm{CB}}$ & $14,14 \pm 1,03^{\mathrm{CA}}$ \\
\hline E. avium & $7,36 \pm 1,10^{\mathrm{cB}}$ & $12,42 \pm 2,20^{\mathrm{bA}}$ & $6,64 \pm 1,40^{\mathrm{cB}}$ & $13,13 \pm 2,14^{\mathrm{cA}}$ \\
\hline P. pentosaceus & $8,68 \pm 1,24^{\mathrm{cB}}$ & $15,16 \pm 2,40^{\mathrm{bA}}$ & $7,76 \pm 0,95^{\mathrm{cB}}$ & $13,86 \pm 1,01^{\mathrm{cA}}$ \\
\hline L. gasseri & $21,37 \pm 2,76^{\mathrm{bB}}$ & $32,57 \pm 1,96^{\mathrm{aA}}$ & $22,77 \pm 1,81^{\mathrm{bB}}$ & $32,30 \pm 0,98^{\mathrm{bA}}$ \\
\hline L. bulgaricus & $30,22 \pm 1,43^{\mathrm{aB}}$ & $36,32 \pm 1,09^{a A}$ & $33,54 \pm 1,56^{\mathrm{aAB}}$ & $33,93 \pm 1,91^{\mathrm{bAB}}$ \\
\hline L. rhamnosus & $17,13 \pm 3,01^{b D}$ & $35,69 \pm 3,13^{a B}$ & $27,79 \pm 2,67^{\mathrm{abc}}$ & $45,67 \pm 1,65^{\mathrm{aA}}$ \\
\hline B. lactis & $16,89 \pm 2,01^{\mathrm{bB}}$ & $36,56 \pm 2,46^{\mathrm{aA}}$ & $23,62 \pm 4,13^{\mathrm{bB}}$ & $35,84 \pm 3,85^{\mathrm{bA}}$ \\
\hline
\end{tabular}

${ }^{1}$ Percentual de toxina removida de uma solução TFS contendo $0,15 \mu \mathrm{g} \mathrm{AFM} / \mathrm{mL}$.

${ }^{2}$ Valores expressos em média \pm desvio padrão de amostras analisadas em triplicata.

${ }^{3}$ Tempo de contato entre a BAL e a AFM 1 em solução TFS (15 min. ou $24 \mathrm{~h}$ ).

${ }^{a-c}$ Em uma mesma coluna, médias seguidas por letras diferentes diferem significativamente $(P<0,05)$.

A-D Em uma mesma linha, médias seguidas por letras diferentes diferem significativamente $(P<0,05)$.

Comparando-se as diferenças encontradas entre os tratamentos aplicados, pode-se observar que, para a maioria das bactérias ( $L$. plantarum, E. avium, $P$. pentosaceus, B. lactis e $L$. gasseri), as células inviáveis apresentaram porcentagens de remoção de $\mathrm{AFM}_{1}$ significativamente maiores que as células viáveis em ambos os tempos de contato analisados, sendo que não houve diferença significativa entre os tempos de 15 minutos e 24 horas para os valores encontrados. Embora para $L$. bulgaricus, as células inviáveis no tempo de 15 minutos apresentaram o maior valor de remoção da $A F M_{1}$, este não diferiu significativamente dos valores para as células viáveis e inviáveis no tempo de 24 horas, enquanto que, para L. rhamnosus, as células inviáveis no tempo de 24 horas mostraram-se significativamente mais eficientes em remover a toxina do meio.

Quando analisadas as diferenças de remoção de $\mathrm{AFM}_{1}$ entre as bactérias estudadas, observou-se que, para as células viáveis no tempo de 15 minutos, $L$. bulgaricus mostrou-se a mais eficiente, entretanto, para as células inviáveis no mesmo tempo de remoção, não houve diferença significativa entre $L$. bulgaricus, $L$. rhamnosus, B. lactis e L. gasseri. Já no tempo de contato de 24 horas, as células viáveis de L. bulgaricus apresentaram o maior valor de remoção de AFM 1 , embora este não tenha sido significativamente diferente do valor apresentado por $L$. 
rhamnosus, que foi o mais eficiente em remover a toxina para o tratamento com células inviáveis.

Sarimehmetoglu \& Küplülü (2004) encontraram valores bastante semelhantes em seu trabalho, pois células viáveis de Lactobacillus delbrueckii spp. bulgaricus $\mathrm{CH}-2$ removeram $29,42 \%$ da $\mathrm{AFM}_{1}$ presente em uma solução TFS no tempo de contato de 4 horas a $37^{\circ} \mathrm{C}$. Os autores também avaliaram a capacidade de Streptococcus thermophilus ST-36 observando-se 18,70\% de remoção da $\mathrm{AFM}_{1}$ do meio. Até hoje, apenas uma bactéria, Flavobacterium aurantiacum NRRL B-184, conseguiu remover $100 \%$ da $\mathrm{AFM}_{1}$ de um meio líquido contaminado, utilizando-se uma concentração celular de $5 \times 10^{10} \mathrm{UFC} / \mathrm{mL}$ e tempo de contato de 4 horas (LILLEHOJ et al., 1971).

Kabak \& Var (2008) avaliaram a capacidade de 4 cepas de Lactobacillus spp. e 2 cepas de Bifidobacterium spp. em remover a AFM 1 em TFS e observaram que as células viáveis das 6 cepas removeram de 10,22\% a 26,65\% da AFM 1 presente na solução, dependendo do nível de contaminação e do período de incubação, enquanto que as células inviáveis removeram de 14,04\% a 28,97\% da toxina. Os pesquisadores concluíram que o processo de remoção foi rápido, não havendo diferenças significativas entre os tempos de contato de 0,4 e 24 horas, contrariamente ao observado por Elgerbi et al. (2006) para cepas de Lactobacillus spp., Lactococcus spp. e Bifidobacterium spp., que no tempo de 24 horas apresentaram porcentagens de remoção variando entre $0 \%$ e $14,6 \%$, e para o tempo de 96 horas entre $4,5 \%$ a $73,1 \%$.

Em relação à concentração de células bacterianas no meio, Kabak \& Var (2008) concluíram que houve uma diminuição significativa na quantidade de $\mathrm{AFM}_{1}$ removida quando a quantidade de células passou de $10^{7} \mathrm{UFC} / \mathrm{mL}(0 \%$ a 5,02\%) para $10^{8} \mathrm{UFC} / \mathrm{mL}(10,22 \%$ a $26,65 \%)$, indicando que a população bacteriana é um fator crítico para a remoção de $\mathrm{AFM}_{1}$ pelas BAL. Bolognani et al. (1997) observaram que uma concentração mínima de $5 \times 10^{9} \mathrm{UFC} / \mathrm{mL}$ de Lactobacillus acidophilus ou Bifidobacterium longum é necessária para remover apenas $13 \%$ da $A_{F} B_{1}$ em cerca de uma hora.

El-Nezami et al. (1998b) relataram que, para Lactobacillus rhamnosus (cepas GG e LC705), foi preciso uma concentração mínima de $2 \times 10^{9} \mathrm{UFC} / \mathrm{mL}$ para remover $50 \%$ da $\mathrm{AFB}_{1}$, sendo que uma remoção maior aconteceu quando a 
concentração de BAL foi elevada para $10^{10} \mathrm{UFC} / \mathrm{mL}$. Complementarmente, os autores observaram que bactérias gram-positivas são melhores sequestradoras de aflatoxina do meio que bactérias gram-negativas, com taxas de remoção de $80 \% \mathrm{e}$ $20 \%$, respectivamente, sugerindo que a habilidade de remoção da toxina é dependente da estrutura da parede celular. Lee et al. (2003) afirmam que a concentração de aflatoxina no meio também influencia a taxa de adsorção da mesma, concluindo que quanto maior a sua concentração no meio maior é a taxa de remoção, tanto para as células viáveis quanto para as inviáveis.

Pierides et al. (2000) analisaram a habilidade de células viáveis e tratadas termicamente de 8 cepas de BAL em remover a $A F M_{1}$ em TFS a $37^{\circ} \mathrm{C}$ após cerca de 16 horas de tempo de contato e obtiveram resultados variando de $18,1 \%$ a $53,8 \%$ para as células viáveis e de $25,5 \%$ a $61,5 \%$ para as inviáveis. A bactéria Lactobacillus Gasseri (ATCC 33323), a mesma utilizada nesse estudo, apresentou $30,8 \%$ de remoção para as células viáveis e $61,5 \%$ de remoção para as células inviáveis. Os pesquisadores observaram que Lactobacillus rhamnosus (cepas GG e LC705) foram as bactérias que apresentaram os melhores valores de remoção tanto para as células viáveis $(50,7 \%$ e $46,3 \%$, respectivamente) quanto para as células inviáveis (57,8\% e $51,6 \%$, respectivamente), assim, compararam seus resultados com os obtidos por El-Nezami et al. (1998b) para a remoção de $\mathrm{AFB}_{1}$ na mesma solução pelas mesmas bactérias $(77,0 \%$ e $65,0 \%$, respectivamente) e concluíram que a remoção da $A F M_{1}$ foi menos efetiva possivelmente devido à presença de um grupo $-\mathrm{OH}$ adicional em sua molécula, o que resulta em um aumento da polaridade da mesma, tornando-a mais hidrofílica e aumentando sua tendência em ficar retida em soluções aquosas.

Pelos resultados encontrados neste trabalho e nos demais citados, percebese que a viabilidade bacteriana não é um pré-requisito para a remoção de $A F M_{1}$ por BAL. Embora o mecanismo de ação dessas bactérias sobre as aflatoxinas ainda não tenha sido esclarecido, sugeri-se que, pelo fato de as células inviáveis conseguirem também realizar essa remoção da toxina, ocorra uma união de natureza física com a mesma, ou seja, uma adesão aos componentes da parede celular bacteriana, principalmente aos polissacarídeos e aos peptidoglicanos, ao invés de ocorrer através de ligação covalente ou degradação pelo metabolismo da bactéria (BATA \& LASZTITY, 1999; LAHTINEN et al., 2004; SHETTY \& JESPERSEN, 2006). 
Tanto os polissacarídeos quanto os peptidoglicanos da parede celular bacteriana devem ser muito afetados pelos tratamentos térmico e ácido. $\mathrm{O}$ calor pode causar a desnaturação de proteínas, aumentando a natureza hidrofóbica de sua superfície, ou a formação de produtos da reação de Maillard. Já o ácido pode romper as ligações glicosídicas em polissacarídeos, liberando monômeros que podem ser ainda mais fragmentados em aldeídos, degradando também as proteínas até componentes menores como peptídeos e aminoácidos. Assim, o tratamento ácido pode quebrar a estrutura do peptidoglicano, comprometendo sua integridade estrutural, isto é, diminuindo a espessura dessa camada, reduzindo as ligações cruzadas e aumentando o tamanho dos poros. Essas perturbações causadas por esses tratamentos permitem que a aflatoxina se vincule à parede celular bacteriana e aos componentes da membrana plasmática, os quais não estavam disponíveis quando a célula bacteriana estava intacta (HASKARD et al., 2001).

Hernandez-Mendoza et al. (2009b) explicam que a integridade da parede celular bacteriana é importante no processo de remoção de aflatoxina para células viáveis e inviáveis. Em seu estudo com $\mathrm{AFB}_{1}$, puderam verificar que tanto a parede celular bacteriana quanto seus fragmentos purificados foram capazes de remover a aflatoxina do meio, entretanto, quando ocorreu a perda ou destruição da parede celular (total ou parcial) em resposta a tratamentos enzimáticos, uma diminuição significativa da capacidade de remoção foi observada.

Haskard et al. (2000) estudaram a capacidade de L. rhamnosus GG em unirse à $\mathrm{AFB}_{1}$, observando pouca diferença entre a remoção de aflatoxina pelas células tratadas termicamente e com ácido ( $85 \%$ e $91 \%$, respectivamente), em relação às células viáveis da bactéria ( $86 \%)$. Os autores também observaram que a adição de uréia ao meio, a qual é um agente anti-hidrofóbico, diminuiu significativamente a remoção da toxina para as células inviáveis, de $85 \%$ a $91 \%$ para $50 \%$ a $60 \%$, mostrando que interações hidrofóbicas possuem um papel relevante. Além disso, a adição de diferentes concentrações de $\mathrm{NaCl}$ e $\mathrm{CaCl}_{2}$ (de 0,01 a $1 \mathrm{M}$ ) e uma variação de $\mathrm{pH}$ de 2,5 a 8,5 praticamente não apresentaram efeitos sobre a remoção da AFB 1 pela bactéria, sugerindo que ligações de hidrogênio e interações eletrostáticas não são importantes.

Em tratamentos utilizando pronase $\mathrm{E}$, lipase e periodato, o tratamento com periodato produziu significativas reduções na capacidade de remoção da $A F B_{1}$ tanto 
para as células viáveis quanto para as inviáveis, já que causa a oxidação dos grupos -OH cis em grupos aldeídos e ácido-carboxílicos, sugerindo que a união ocorre predominantemente com os polissacarídeos da bactéria. $O$ tratamento com pronase E causou a mesma redução significativa na remoção da $A F B_{1}$, evidenciando que proteínas podem estar também envolvidas no processo. Assim, o fato da pronase $E$ e periodato terem ambos um efeito significativo sobre a remoção de $A F B_{1}$, indica que os sítios de ligação são de natureza protéica. Já a lipase não causou nenhuma diminuição significativa na remoção da $\mathrm{AFB}_{1}$, mostrando que a participação de lipídios, como o ácido lipoteicóico, é pouco provável (HASKARD et al., 2001). Embora os tratamentos utilizados diminuíssem a remoção de $\mathrm{AFB}_{1}$, em todos os casos esta ainda continuou ocorrendo em quantidades substanciais, mostrando possivelmente um envolvimento de múltiplos componentes na ligação com a micotoxina (HASKARD et al., 2001).

A estabilidade do complexo BAL/AFM 1 em uma ampla faixa de $\mathrm{pH}$ é um fator importante para o uso desses microrganismos com o fim de remover a aflatoxina em alimentos, já que a liberação da toxina durante a passagem gástrica teria implicações negativas para a saúde, de modo que o complexo formado deve resistir aos principais estresses ambientais causados pelo trato gastrointestinal, como 0 baixo $\mathrm{pH}$ e a presença de bile. Nenhum estudo avaliando-se essa característica para $\mathrm{AFM}_{1}$ foi publicado até o momento, apenas estudos utilizando-se AFB 1 . Analisandose a influência da presença de bile sobre o complexo BAL/ $\mathrm{AFB}_{1}$ formado, observouse que Lactobacillus casei removeu mais $\mathrm{AFB}_{1}$ quando exposta à bile, sugerindo que essa exposição causa modificações na estrutura e na composição da parede celular da bactéria, induzindo provavelmente à formação de novos sítios de ligação para a aflatoxina, ou, então, aumentando o tamanho dos sítios já existentes (HERNANDEZMENDOZA et al., 2009a).

El-Nezami et al. (2000a) investigaram a habilidade de L. rhamnosus (cepas GG e LC705) e Propionibacterium freudenreichii spp. shermanii JS em remover a $\mathrm{AFB}_{1}$ de um meio líquido intestinal extraído do duodeno de frangos, e observaram que a concentração de $A F B_{1}$ reduziu $54 \%$ em apenas 1 minuto na presença de $L$. rhamnosus GG, enquanto que apenas 44\% na presença de L. rhamnosus LC705 e $36 \%$ na presença de $P$. freudenreichii spp. shermanii JS. Os autores verificaram que o acúmulo de $A F B_{1}$ no tecido intestinal apresentou redução de $74 \%$, 63\% e 37\%, 
respectivamente para $L$. rhamnosus (cepas GG e LC705) e P. freudenreichii spp. shermanii JS, mostrando que essas bactérias podem afetar a biodisponibilidade da aflatoxina e serem utilizadas para redução da sua toxicidade em humanos e animais.

No Egito, um ensaio piloto investigou o efeito da adição de L. rhamnosus LC705 e $P$. freudenreichii spp. shermanii JS na dieta de pessoas sobre os níveis de aflatoxinas em amostras fecais. Observou-se que 11 das 20 pessoas voluntárias apresentaram $\mathrm{AFB}_{1}$ nas fezes em quantidades que variavam de 1,8 a $6 \mu \mathrm{g} \mathrm{AFB}{ }_{1} / \mathrm{kg}$ fezes, sendo que após duas semanas de suplementação com as bactérias probióticas houve uma redução significativa nesse nível de excreção, mostrando que essas cepas possuem a habilidade de influenciar a conteúdo de $\mathrm{AFB}_{1}$ nas fezes (ELNEZAMl et al., 2000b).

\subsection{Avaliação da estabilidade do complexo BAL/AFM}

Visando à análise da capacidade de retenção da $A F M_{1}$ pelas bactérias, efetuou-se a lavagem com solução TFS dos pellets bacterianos contendo a $A F M_{1}$ adsorvida. Após a análise do sobrenadante por CLAE, obteve-se os dados visualizados na Tabela 6.

Observa-se que as porcentagens de $\mathrm{AFM}_{1}$ liberadas de volta para a solução pelas bactérias após a lavagem variaram de $40,57 \%$ a $87,37 \%$. As células viáveis de L. rhamnosus com tempo de contato de 15 minutos foram as que mais desprenderam a aflatoxina de volta para o meio. Esta bactéria apresentou diferenças significativas entre todos os tratamentos por que passou, entretanto, entre as bactérias não diferiu significativamente de $B$. lactis e $L$. gasseri. A bactéria que menos liberou a $A F M_{1}$ para a solução foi $E$. avium, no tratamento com células viáveis e tempo de 24 horas, embora esta não tenha diferido significativamente de suas células inviáveis no tempo de 24 horas e das células viáveis de L. bulgaricus no tempo de 24 horas. 
Tabela 6 - Percentual ${ }^{1}$ de $\mathrm{AFM}_{1}$ recuperada em solução após lavagem com TFS ${ }^{2}$.

\begin{tabular}{|c|c|c|c|c|}
\hline \multirow{2}{*}{ Bactérias } & \multicolumn{4}{|c|}{$\%$ de $\mathrm{AFM}_{1}$ liberada pela bactéria } \\
\hline & Viável 15min ${ }^{3}$ & Inviável 15min & Viável 24h & Inviável 24h \\
\hline L. plantarum & $66,41 \pm 6,22^{\mathrm{bcA}}$ & $62,77 \pm 3,49^{\mathrm{aAB}}$ & $68,87 \pm 2,49^{\mathrm{aA}}$ & $53,79 \pm 3,82^{\mathrm{abB}}$ \\
\hline E. avium & $70,52 \pm 7,31^{\mathrm{bcA}}$ & $57,00 \pm 5,76^{\mathrm{aA}}$ & $40,57 \pm 4,66^{\mathrm{cB}}$ & $56,71 \pm 6,94^{\mathrm{abAB}}$ \\
\hline P. pentosaceus & $61,79 \pm 5,69^{\mathrm{cA}}$ & $57,08 \pm 5,93^{\mathrm{aA}}$ & $70,25 \pm 8,33^{\mathrm{aA}}$ & $60,64 \pm 7,57^{\mathrm{abA}}$ \\
\hline L. bulgaricus & $63,04 \pm 3,87^{\mathrm{CAB}}$ & $65,57 \pm 5,30^{\mathrm{aAB}}$ & $53,90 \pm 6,51^{\mathrm{bcB}}$ & $69,29 \pm 4,45^{\mathrm{aA}}$ \\
\hline L. rhamnosus & $87,37 \pm 1,82^{\mathrm{aA}}$ & $64,51 \pm 4,17^{\mathrm{aB}}$ & $59,42 \pm 1,97^{\mathrm{abB}}$ & $49,16 \pm 3,83^{b c}$ \\
\hline B. lactis & $79,54 \pm 7,62^{\mathrm{abA}}$ & $62,93 \pm 9,21^{\mathrm{aAB}}$ & $58,07 \pm 7,20^{\mathrm{abB}}$ & $59,22 \pm 8,22^{a b A B}$ \\
\hline L. gasseri & $79,14 \pm 4,26^{\mathrm{abA}}$ & $63,40 \pm 3,79^{a B}$ & $63,73 \pm 0,95^{\mathrm{abB}}$ & $64,31 \pm 1,32^{\mathrm{abB}}$ \\
\hline \multicolumn{5}{|c|}{ Percentual de toxina liberada pela bactéria após lavagem com solução TFS. } \\
\hline \multicolumn{5}{|c|}{${ }^{2}$ Valores expressos em média \pm desvio padrão de amostras analisadas em triplicata. } \\
\hline \multicolumn{5}{|c|}{${ }^{3}$ Tempo de contato entre a BAL e a AFM 1 em solução TFS (15 min. ou 24 h). } \\
\hline \multicolumn{5}{|c|}{ a-c Em uma mesma coluna, médias seguidas por letras diferentes diferem significativamente $(P<0,05)$. } \\
\hline
\end{tabular}

Elgerbi et al. (2006) observaram que após a primeira lavagem dos pellets bacterianos com TFS, a proporção de $\mathrm{AFM}_{1}$ liberada pelas bactérias foi de $87,3 \%$ para as cepas de Lactobacillus spp., 85,7\% para as cepas de Lactococcus spp. e de 85,7\% para as cepas de Bifidobacterium spp. Também observaram que após a terceira lavagem, praticamente todas as bactérias haviam liberado toda a AFM adsorvida de volta para o meio $(92,0 \%$ a $100 \%)$.

Kabak \& Var (2008) concluíram que a remoção de $\mathrm{AFM}_{1}$ pelas bactérias foi reversível e que pequenas quantidades de toxina voltaram para a solução TFS (5,62\% a 8,54\%). Isso é consistente com o encontrado por Haskard et al. (2001), que observaram que L. rhamnosus GG, L. rhamnosus LC-705 e Lactobacillus casei Shirota liberaram $3,7 \%, 3,0 \%$ e 2,4\%, respectivamente, da $\mathrm{AFB}_{1}$ de volta para a solução; mas contrasta com o observado por Peltonem et al. (2001), pois a liberação de $\mathrm{AFB}_{1}$ de volta para a solução na primeira lavagem foi de $48,6 \%, 30,7 \%$ e $26,5 \%$ para Lactobacillus amylovorus (cepas CSCC 5160 e CSCC 5197) e L. rhamnosus LC $1 / 3$, respectivamente. Após 5 lavagens, a $\mathrm{AFB}_{1}$ adsorvida por $L$. amylovorus CSCC 5160 foi quase que completamente liberada $(94,4 \%)$, enquanto que $L$. amylovorus CSCC 5197 e L. rhamnosus Lc 1/3 preservaram retida apenas 17,4\% e 32,2\%, respectivamente, da $\mathrm{AFB}_{1}$ existente na solução original de incubação. 
Assim, percebe-se que o complexo BAL/aflatoxina formado é instável, já que parte da aflatoxina, tanto $A F B_{1}$ quanto $A F M_{1}$, se libertou do complexo após as lavagens e retornou gradualmente para a solução aquosa. Deste modo, quanto maior foi o número de lavagens, mais aflatoxina foi liberada para a solução, mostrando que a ligação que as unia não era forte e sugerindo que essa ligação era não-covalente fraca, ocorrendo uma associação a sítios hidrofóbicos na superfície bacteriana (PELTONEM et al., 2001; HASKARD et al., 2000).

Contrariamente a esta hipótese, D'Souza \& Brackett (2001), realizando as mesmas lavagens sobre o complexo formado entre Flavobacterium aurantiacum e $A F B_{1}$, observaram que não houve liberação da aflatoxina na solução aquosa e Hernandez-Mendoza et al. (2009a) analisando a estabilidade do complexo formado entre $\mathrm{AFB}_{1}$ e 8 cepas de Lactobacillus casei após as lavagens demonstrou que as quantidades de aflatoxina que foram liberadas variaram entre praticamente zero e $9,2 \%$. Possíveis explicações para essa variação na liberação da aflatoxina incluem as diferenças nos sítios de ligação presentes nas diferentes cepas, ou, então, mais provavelmente, que esses sítios de ligação são similares, mas que apresentam diferenças mínimas dependendo de cada cepa. Hernandez-Mendoza et al. (2009b) explicam que uma menor liberação da toxina para o meio após as lavagens pode ser atribuída às interações entre as moléculas de aflatoxina retidas na parede celular de uma bactéria com as moléculas retidas na parede celular da bactéria adjacente, formando uma espécie de matriz reticulada que impede a liberação da aflatoxina. Lee et al. (2003) sugerem que quanto mais moléculas de aflatoxina forem removidas pela célula bacteriana, mais tempo essas moléculas permanecerão adsorvidas na superfície celular.

\subsection{Remoção da $\mathrm{AFM}_{1}$ em leite UHT desnatado}

A fim de testar a capacidade das BAL em remover a $A F M_{1}$ em uma matriz alimentícia, foram selecionadas as três cepas (Lactobacillus rhamnosus, Lactobacillus delbrueckii spp. bulgaricus and Bifidobacterium lactis) que apresentaram os maiores resultados de remoção da toxina em solução TFS para 
realização de ensaios com leite UHT desnatado. Os resultados obtidos para esses ensaios de remoção estão na Tabela 7.

Tabela 7 - Percentual de remoção ${ }^{1}$ da $\mathrm{AFM}_{1}$ em leite UHT desnatado².

\begin{tabular}{ccc}
\hline Bactérias & \multicolumn{2}{c}{$\%$ de Remoção de $\mathbf{A F M}_{\mathbf{1}}$} \\
\cline { 2 - 3 } & $\mathbf{4}^{\circ} \mathbf{C}$ & $\mathbf{3 7 ^ { \circ } \mathbf { C }}$ \\
\hline L. bulgaricus & $13,51 \pm 5,26^{\mathrm{bB}}$ & $33,54 \pm 9,74^{\mathrm{aA}}$ \\
L. rhamnosus & $19,70 \pm 5,14^{\mathrm{bA}}$ & $24,46 \pm 3,82^{\mathrm{aA}}$ \\
B. lactis & $37,75 \pm 3,31^{\mathrm{aA}}$ & $32,54 \pm 4,01^{\mathrm{aA}}$ \\
\hline${ }^{1}$ Percentual de toxina removida de leite UHT desnatado contendo $0,5 \mu \mathrm{g} \mathrm{AFM}_{1} / \mathrm{L}$ após 15 minutos. \\
${ }^{2}$ Valores expressos em média \pm desvio padrão de amostras analisadas em triplicata. \\
${ }^{\mathrm{a}-\mathrm{b}}$ Em uma mesma coluna, médias seguidas por letras diferentes diferem significativamente $(\mathrm{P}<0,05)$. \\
${ }^{\mathrm{A}-\mathrm{B}}$ Em uma mesma linha, médias seguidas por letras diferentes diferem significativamente $(\mathrm{P}<0,05)$.
\end{tabular}

Comparando-se os tratamentos realizados, isto é, os resultados obtidos para as temperaturas de $4^{\circ} \mathrm{C}$ e $37^{\circ} \mathrm{C}$, observa-se que não houve diferença significativa para as bactérias $L$. rhamnosus e $B$. lactis, apenas para $L$. bulgaricus, a qual apresentou melhor capacidade de remoção da $A F M_{1}$ à $37^{\circ} \mathrm{C}$. Já na análise comparativa entre as bactérias, percebeu-se que, à temperatura de $37^{\circ} \mathrm{C}$, não houve diferença significativa entre as três cepas estudadas. Entretanto, à $4^{\circ} \mathrm{C}, \mathrm{B}$. lactis mostrou-se mais eficiente em remover a micotoxina do leite. El-Nezami et al. (1998b) observaram uma maior eficiência de remoção de $A F B_{1}$ a $37^{\circ} \mathrm{C}$ ao invés de $4{ }^{\circ} \mathrm{C}$ e $25^{\circ} \mathrm{C}$, enquanto que Zinedine et al. (2005) verificaram uma melhor atividade de remoção da $A F B_{1}$ a temperatura de $25^{\circ} \mathrm{C}$, ao invés de $15^{\circ} \mathrm{C}$ ou $37^{\circ} \mathrm{C}$ para todos os 12 tipos de BAL analisados. Em contraste, Haskard et al. (2001) não observaram mudanças significativas na estabilidade do complexo formado entre $A_{F} B_{1}$ e $L$. rhamnosus (GG e LC-705) na faixa de temperatura de $4^{\circ} \mathrm{C}$ a $37^{\circ} \mathrm{C}$.

Em relação aos resultados de remoção da $\mathrm{AFM}_{1}$ por células inviáveis em solução TFS a $37^{\circ} \mathrm{C}$ no tempo de 15 minutos, demonstrados no item 4.2 , os valores encontrados para o leite são relativamente menores. Pierides et al. (2000) encontraram resultados similares em seu trabalho, pois células inviabilizadas termicamente de L. rhamnosus (cepas GG e LC705) removeram a AFM 1 de leite em pó reconstituído desnatado (18,8\% e 27,4\%, respectivamente) e integral $(26,0 \%$ e 
$30,1 \%$, respectivamente) a $37^{\circ} \mathrm{C}$ após 16 horas de contato, enquanto que em TFS esses valores foram de $57,8 \%$ e $51,6 \%$, respectivamente. Os autores concluíram que essa menor efetividade de remoção, em relação à solução TFS, pode ser explicada pelo fato de a $A F M_{1}$ possivelmente não estar acessível no leite, isto é, estar associada à caseína, sendo que a interferência das proteínas no processo de remoção pode ser responsável pela diferença entre os leites desnatado e integral (aproximadamente $10 \%$ menor), já que o leite desnatado em pó utilizado continha $37 \mathrm{~g}$ proteína $/ 100 \mathrm{~g}$, enquanto que o conteúdo protéico do leite integral em pó era de $25 \mathrm{~g}$ proteína/100g.

Contrariamente, Elgerbi et al. (2006) observaram maiores porcentagens de remoção da AFM 1 em leite UHT por cepas de Lactobacillus spp., Lactococcus spp. e Bifidobacterium spp. em todos os tempos analisados (24, 48, 72 e 96 horas). Após 96 horas, enquanto no leite UHT as bactérias haviam removido de $46,0 \%$ a $80,5 \%$ da $\mathrm{AFM}_{1}$, em TFS essa remoção foi de $4,5 \%$ a $73,1 \%$, sendo Lactobacillus bulgaricus (NCFB 1489) foi o responsável pela maior remoção no leite $(80,5 \%)$ e Lactobacillus plantarum (DSM 12028) em TFS (73,1\%).

Sarimehmetoglu \& Küplülü (2004) também obtiveram melhores resultados de remoção da $A F M_{1}$ para leite reconstituído (12\% de matéria seca não gordurosa). Lactobacillus delbrueckii subsp. bulgaricus $\mathrm{CH}-2$ e Streptococcus thermophilus ST36 removeram a $A F M_{1}$ em $18,70 \%$ e $29,42 \%$, respectivamente, em solução TFS, e $27,56 \%$ e $39,16 \%$, respectivamente, em leite reconstituído. Possivelmente, essa maior remoção pode ser devido à menor quantidade de matéria seca não gordurosa, já que Brackett \& Marth (1982) reportaram que 30,7\% mais AFM foi encontrada em leite tratado com enzima proteolítica, sugerindo a ligação da $A F M_{1}$ à proteína do leite. Kabak \& Var (2008) não observaram diferenças significativas entre a capacidade de remover a AFM 1 em solução TFS ou em leite desnatado após 4 horas de incubação, concluíram que haviam diferenças significativas apenas entre as espécies bacterianas, não entre a capacidade de remoção da $\mathrm{AFM}_{1}$ pelas células viáveis $(7,85 \%$ a $25,94 \%)$ e inviáveis (12,85\% a $27,31 \%)$.

Os métodos de remoção de aflatoxinas empregando-se as BAL, principalmente aquelas que já são atualmente utilizadas em produtos alimentícios, podem ser rentáveis, comercialmente viáveis e seguros para a aplicação em alimentos funcionais probióticos e em alimentos líquidos como leite e óleos, além de 
rações para animais evitando-se os efeitos negativos das micotoxinas em carnes, ovos e leite.

Os resultados existentes até o momento mostram que as células bacterianas, tanto viáveis quanto inviáveis, podem ser utilizadas como agentes descontaminantes, pois ambas apresentam essa habilidade de remoção de $\mathrm{AFM}_{1}$ de um meio líquido em um tempo relativamente pequeno. A maioria dos estudos aponta que as células inviáveis de bactérias são menos prováveis de liberar a aflatoxina adsorvida de volta para meio e para trato gastrointestinal, podendo, assim, serem incorporadas a alimentos, prevenindo a adsorção da toxina pelas células do epitélio intestinal, reduzindo sua biodisponibilidade, e, principalmente, não alterando o sabor e a acidez dos alimentos. Entretanto, muitos estudos ainda são necessários a fim de investigar outras possíveis variáveis do processo de remoção, tais como a quantidade máxima de micotoxina removida pela bactéria, os requerimentos estruturais para essa remoção, a variação da remoção sob diferentes condições de processamento dos alimentos e os efeitos das bactérias sobre a biodisponibilidade das aflatoxinas não removidas (LEE et al., 2003; EL-NEZAMI et al., 2004).

Para a indústria de laticínios, uma opção bastante interessante seria a utilização das BAL na forma imobilizada, criando-se uma espécie de filtro que retém a $A F M_{1}$, ou seja, o leite passa por esse filtro a uma determinada velocidade por um tempo suficiente para que ocorra o processo de remoção. Assim, obtém-se um leite parcial ou totalmente livre de contaminação por $\mathrm{AFM}_{1}$, podendo ser utilizado em outros processos subsequentes, sem ter suas características próprias alteradas.

Oluwafemi \& Da Silva (2009) explicam que os métodos biológicos de descontaminação podem também apresentar algumas limitações como degradação incompleta da toxina, tempo de degradação longo, inadaptabilidade aos sistemas alimentícios, pigmentação da cultura e produção de odores, os quais podem reduzir seu potencial para o uso na indústria de alimentos. Entretanto, a possibilidade de utilização das células bacterianas inviáveis resolveria praticamente todos esses problemas. 


\section{Conclusões}

De acordo com os resultados obtidos no presente estudo, e considerando-se os objetivos propostos, pode-se concluir que:

1) A remoção da $A F M_{1}$ pelas cepas de $B A L$ em solução $T F S$ a $37^{\circ} \mathrm{C}$ variou entre 5,60 e 45,67\%, sendo que as células inviáveis apresentaram percentuais de remoção de $A F M_{1}$ significativamente maiores que as células viáveis;

2) Não houve diferenças significativas na remoção da $A F M_{1}$ pelas cepas de BAL em solução TFS a $37^{\circ} \mathrm{C}$ entre os tempos de 15 minutos e 24 horas;

3) As células viáveis de Lactobacillus delbrueckii spp. bulgaricus foram as que apresentaram o maior percentual de remoção da $A F M_{1}$ em solução TFS no tempo de contato de 15 minutos, diferindo significativamente de todas as outras bactérias;

4) As células inviáveis de Lactobacillus rhamnosus foram as que apresentaram o maior percentual de remoção da $\mathrm{AFM}_{1}$ em solução TFS no tempo de contanto de 24 horas, com diferenças significativas em relação às demais bactérias;

5) O complexo formado entre as BAL analisadas e a AFM ${ }_{1}$ em solução TFS é altamente instável, sendo que a quantidade de aflatoxina liberada de volta para a solução variou amplamente de cepa para cepa;

6) As células viáveis de Lactobacillus rhamnosus com tempo de contato de 15 minutos foram as que mais desprenderam a aflatoxina de volta para o meio, diferindo significativamente entre todos os tratamentos e bactérias, exceto de B. lactis e L. gasseri;

7) Os percentuais de remoção de $A F M_{1}$ nos ensaios realizados em leite UHT desnatado variaram entre 13,51 e $37,75 \%$, sendo que Lactobacillus bulgaricus foi a única bactéria que apresentou diferença significativa entre as temperaturas aplicadas, com maior eficiência a $37^{\circ} \mathrm{C}$; 
8) Ainda no leite, comparando-se as bactérias, observou-se que a $37^{\circ} \mathrm{C}$ não houve diferença significativa entre elas, entretanto, Bifidobacterium lactis mostrou-se mais eficiente na remoção da aflatoxina do leite a $4^{\circ} \mathrm{C}$;

9) Os resultados demonstraram que há perspectiva para utilização das cepas de BAL estudadas para remoção de $\mathrm{AFM}_{1}$ em matrizes alimentícias. Entretanto, estudos adicionais são necessários a fim de investigar os mecanismos envolvidos na remoção da toxina pelas BAL com vistas à aplicação em indústrias de alimentos. 


\section{Referências}

ABBAS, H.K. Aflatoxin and food safety. Boca Raton: CRC Press, 2005.

ALBERTS, J.F.; ENGELBRECHT, Y.; STEYN, P.S.; HOLZAPFEL, W.H.; van ZYL, W.H. Biological degradation of aflatoxin $\mathrm{B}_{1}$ by Rhodococcus erythropolis cultures. International Journal of Food Microbiology, v.109, p.121-126, 2006.

ALBERTS, J.F.; GELDERBLOMB, W.C.A.; BOTHA, A.; van ZYL, W.H. Degradation of aflatoxin $B_{1}$ by fungal laccase enzymes. International Journal of Food Microbiology, v.135, p.47-52, 2009.

[APHA] AMERICAN PUBLIC HEALTH ASSOCIATION. Standard methods for the examination of dairy products. 17.ed. Washington, DC: APHA, 2004.

AN, Z. Handbook of Industrial Mycology. v.22. New York: Marcel Dekker, 2005.

AZAB, R.M.; TAWAKKOL, W.M.; HAMAD, A.R.M; ABOU-ELMAGD, M.K.; ELAGRAB, H.M.; REFAI, M.K. Detection and Estimation of Aflatoxin $B_{1}$ in Feeds and its Biodegradation by Bacteria and Fungi. Egyptian Journal of Natural Toxins, v.2, p.3956, 2005.

BAKIRCI, I. A study on the occurrence of aflatoxina $M_{1}$ in milk and milk products produced in Van province of Turkey. Food Control, v.12, p.47-51, 2001.

BARTOSZEK, A. Genotoxic Food Components. In: MALEJKA-GIGANTI, D.; BARTOSZEK, A.; BAER-DUBOWSKA, W. Carcinogenic and Anticarcinogenic Food Components. CRC Press, 2006. Cap. 4, p.69-96.

BATA, A.; LASZTITY, R. Detoxification of mycotoxin-contaminated food and feed by microorganisms. Trends Food Science \& Technology, v.10, p.223-228, 1999.

BEGOT, C.; DESNIER, I.; DAUDIN, J.D.; LABADIE, J.C.; LEBERT, A. Recommendations for calculating growth parameters by optical density measurements. Journal of Microbiological Methods, v.25, p.225-232, 1996.

BHAT, R.; RAI, R.V.; KARIM, A.A. Mycotoxins in Food and Feed: Present Status and Future Concerns. Comprehensive Reviews in Food Science and Food Safety, v.9, p.57-81, 2010. 
BIERNASIAK, J.; PIOTROWSKA, M.; LIBUDZISZ, Z. Detoxification of mycotoxins by probiotic preparation for broiler chickens. Mycotoxin Research, v.22, n.4, p.230-235, 2006.

BOLOGNANI, F.; RUMNEY, C.J.; ROWLAND, I.R. Influence of carcinogen binding by lactic acid-producing bacteria on tissue distribution and in vivo mutagenicity of dietary carcinogens. Food and Chemical Toxicology, v.35, p.535-545, 1997.

BRACKETT, R.E.; MARTH, E.H. Association of aflatoxin $\mathrm{M}_{1}$ with casein. Zeitschrift für Lebensmitteluntersuchung Unters Forschung A, v.174, n.6, p.439-441, 1982.

BRASIL. Ministério da Agricultura. Portaria MAARA n¹83, de 21 de março de 1996. Adota Regulamento Técnico MERCOSUL sobre seus limites máximos admissíveis no leite, amendoim e milho. Diário Oficial da União - D.O.U., de 25 de março de 1996.

BRASIL. Ministério da Saúde. Resolução RDC n² 274, de 15 de outubro de 2002 da ANVISA. Aprova o Regulamento Técnico Sobre Limites Máximos de Aflatoxinas Admissíveis no Leite, no Amendoim e no Milho. Diário Oficial da União - D.O.U., de 16 de outubro de 2002.

ÇELIK, T.H.; SARIMEHMETOGLU, B.; KÜPLÜLÜ, Ö. Aflatoxin M $\mathrm{M}_{1}$ contamination in pasteurized milk. Veterinarski Arhiv, n.75, p.57-65, 2005.

CHU, F.S. Mycotoxins: food contamination, mechanism, carcinogenic potential and preventive measures. Mutation Research, v.259, p.291-306, 1991.

CIEGLER, A.; LILLEHOJ, E.B.; PETERSON, R.E.; HALL, H.H. Microbial detoxification of aflatoxin. Applied and Environmental Microbiology, v.14, n.6, p.934939, 1966.

CREPPY, E.E. Update of survey, regulation and toxic effects of mycotoxins in Europe. Toxicology Letters, v.127, p.19-28, 2002.

D’MELLO, J.P.F.; MACDONALD, A.M.C. Mycotoxins. Animal Feed Science

Technology, v.69, p.155-166, 1997. 
D'SOUZA, D.H.; BRACKETT, R.E. Aflatoxin $\mathrm{B}_{1}$ degradation by Flavobacterium aurantiacum in the presence of reducing conditions and seryl and sulfhydryl group inhibitors. Journal of Food Protection, v.64, n.2, p.268-271, 2001.

ELGERBI, A.M.; AIDOO, K.E.; CANDLISH, A.A.G.; WILLIAMS, A.G. Effects of lactic acid bacteria and bifidobacteria on levels of aflatoxin $M_{1}$ in milk and phosphate buffer. Milchwissenschaft, v.61, n.2, p.197-199, 2006.

EL-NEZAMI, H.; KANKAANPAA, P.; SALMINEN, S. AHOKAS, J. Physicochemical alterations enhance the ability of dairy strains of lactic acid bacteria to remove aflatoxin from contaminated media. Journal of Food Protection, v.61, n.4, p.466-468, 1998a.

EL-NEZAMI, H.; KANKAANPAA, P.; SALMINEN, S. AHOKAS, J. Ability of dairy strains of lactic acid bacteria to bind a common food carcinogen, aflatoxin $B_{1}$. Food and Chemical Toxicology, v.36, p.321-326, 1998b.

EL-NEZAMI, H.; MYKKÄNEN, H.; KANKAANPÄÄ, P.; SALMINEN, S.; AHOKAS, J. Ability of Lactobacillus and Propionibacterium strains to remove aflatoxin $B_{1}$ from the chicken duodenum. Journal of Food Protection, v.63, n.4, p.549-552, 2000a.

EL-NEZAMI, H.S.; MYKKÄNEN, H.; KANKAANPÄÄ, P.; SUOMALAINEN, T.; AHOKAS, J.T.; SALMINEN, S. The ability of a mixture of Lactobacillus and Propionibacterium to influence the faecal recovery of aflatoxins in healthy Egyptian volunteers: a pilot clinical study. Bioscience and Microflora, v.19, p.41-45, 2000b.

EL-NEZAMI, H.; MYKKÄNEN, H.; HASKARD, C.; SALMINEN, S.; SALMINEN, E. Lactic Acid Bacteria as a Tool for Enhancing Food Safety by Removal of Dietary Toxins. In: SALMINEN, S.; VON WRIGHT, A,; OUWEHAND, A. Lactic Acid Bacteria: Microbiological and Functional Aspects. 3.ed. Nova lorque: Marcel Dekker, 2004. Cap. 12, p.397-406.

FAZELI, M.R.; HAJIMOHAMMADALI, M.; MOSHKANI, A.; SAMADI, N.; JAMALIFAR, H.; KHOSHAYAND, M.R.; VAGHARI, E.; POURAGAHI, S. Aflatoxin $B_{1}$ binding capacity of autochthonous strains of lactic acid bacteria. Journal of Food Protection, v.72, n.1, p.189-192, 2009.

FINK-GREMMELS, J. Mycotoxins in cattle feeds and carry-over to dairy milk: A review. Food Additives \& Contaminants: Part A, v.25, n.2, p.172-180, 2008. 
FUCHS, S.; SONTAG, G.; STIDL, R.; EHRLICH, V.; KUNDI, M.; KNASMÜLLER, S. Detoxification of patulin and ochratoxin $A$, two abundant mycotoxins, by lactic acid bacteria. Food and Chemical Toxicology, v.46, p.1398-1407, 2008.

GACULA, J.R.; SINGH, J. Statistical methods in food and consumer research. Orlando: Academic Press, 1984.

GALVANO, F.; GALOFARO, V.; GALVANO, G. Occurrence and stability of aflatoxin $M_{1}$ in milk and milk products: A worldwide review. Journal of Food Protection, v.59, n.10, p.1079-1090, 1996.

GALVANO, F., GALOFARO, V., ANGELIS, A., GALVANO, M., BOGNANNO, M., GALVANO, G. Survey of the occurrence of aflatoxin $\mathrm{M}_{1}$ in dairy products marketed in Italy. Journal of Food Protection, v.61, p.738-741, 1998.

GARRIDO, N.S.; IHA, M.H.; ORTOLANI, M.R.S.; FAVARO, R.M.D. Occurrence of aflatoxins $\mathrm{M}_{1}$ and $\mathrm{M}_{2}$ in milk commercialized in Ribeirão Preto-SP, Brazil. Food Additives and Contaminants, v.20, p.70-73, 2003.

GONÇALEZ, E.; PINTO, M.M.; FELICIO, J.D. Análise de micotoxinas no Instituto Biológico de 1989 a 1999. Divulgação Técnica do Instituto Biológico, Centro de Sanidade Animal, São Paulo, v.63, n.1/2, p.15-19, jan./dez. 2001.

GRATZ, S.; MYKKÄNEM, H.; EL-NEZAMI, H. Aflatoxin $B_{1}$ binding by a mixture of Lactobacillus and Propionibacterium: in vitro versus ex vivo. Journal of Food Protection, v.68, n.11, p.2470-2474, 2005.

HASKARD, C.; BINNION, C.; AHOKAS, J. Factors affecting the sequestration of aflatoxin by Lactobacillus rhamnosus strain GG. Chemico-Biological Interactions, v.128, p.39-49, 2000.

HASKARD, C.A.; EL-NEZAMI, H.S.; KANKAANPÄÄ, P.E.; SALMINEN, S.; AHOKAS, J.T. Surface binding of aflatoxin $\mathrm{B}_{1}$ by lactic acid bacteria. Applied and Environmental Microbiology, v.67, n.7, p.3086-3091, 2001.

HERNANDEZ-MENDOZA, A.; GARCIA, H.S.; STEELE, J.L. Screening of Lactobacillus casei strains for their ability to bind aflatoxin $B_{1}$. Food and Chemical Toxicology, v.47, p.1064-1068, 2009a. 
HERNANDEZ-MENDOZA, A.; GUZMAN-DE-PEÑA, D.; GARCIA, H.S. Key role of teichoic acids on aflatoxin $B_{1}$ binding by probiotic bacteria. Journal of Applied Microbiology, v.107, p.395-403, 2009b.

HUSSEIN, H.S.; BRASEL, J.M. Toxicity, metabolism, and impact of mycotoxins on humans and animals. Toxicology, v.167, p.101-134, 2001.

[IARC] International Agency for Research on Cancer - World Health Organization. Some naturally occurring substances: food items and constituents, heterocyclic aromatic amines and mycotoxins. IARC Monographs on the Evaluation of Carcinogenic Risks to Humans, v.56, p.19-23, 1993.

[IARC] International Agency for Research on Cancer - World Health Organization. IARC Monograph on the Evaluation of Carcinogenic Risk to Humans, v.82, p.171, 2002.

[INCHEM] International Program on Chemical Safety - Chemical Safety Information from Intergovernmental Organizations, 1979. Disponível em:

<http://www.inchem.org/documents/ehc/ehc/ehc011.htm>. Acesso em: 22 dez. 2010.

[JECFA] Joint FAO/WHO Expert Committee on Food Additives. Safety Evaluation of Certain Mycotoxins in Food. $56^{\text {th }}$ meeting of the JECFA - FAO Food and Nutrition Paper 74/WHO Foods Additives Series 47.

KABAK, B.; VAR, I. Factors affecting the removal of aflatoxin $\mathrm{M}_{1}$ from food model by Lactobacillus and Bifidobacterium strains. Journal of Environmental Science and Health Part B, v.43, p.617-624, 2008.

KABAK, B.; DOBSON, A.D.W. Biological strategies to counteract the effects of mycotoxins. Journal of Food Protection, v.72, n.9, p.2006-2016, 2009.

KIM, E.K., SHON, D.H., RYU, D., PARK, J.W., HWANG, H.J., KIM, Y.B. Ocurrence of aflatoxin $\mathrm{M}_{1}$ in Korean dairy products determined by ELISA and HPLC. Food Additives and Contaminants, v.17, p.59-64, 2000.

KUIPER-GOODMAN, T. Uncertainties in the risk assessment of three mycotoxins: aflatoxin, ochratoxin and zearalenone. Canadian Journal of Physiology and Pharmacology, v.68, p.1017-1024, 1990. 
LACIAKOVÁ, A.; CICOÒOVÁ, P.; MÁTÉ, D.; LACIAK, V. Aflatoxins and possibilities for their biological detoxification. Medycyna Weterynaryjna, v.64, n.3, 2008.

LAHTINEN, S.J.; HASKARD, C.A.; OUWEHAND, A.C.; SALMINEN, S.J.; AHOKAS, J.T. Binding of aflatoxin $B_{1}$ to cell wall components of Lactobacillus rhamnosus strain GG. Food Additives and Contaminants, v.21, n.2, p.158-164, 2004.

LEE, Y.K.; EL-NEZAMI, H.; HASKARD, C.A.; GRATZ, S.; PUONG, K.Y.; SALMINEN, S.; MYKKÄNEN, H. Kinetics of Adsorption and Desorption of Aflatoxin $B_{1}$ by Viable and Nonviable Bacteria. Journal of Food Protection, v.66, n.3, p.426-430, 2003.

LILLEHOJ, E.B.; STUBBLEFIELD, R.D.; SHANNON, G.M.; SHOTWELL, O.L. Aflatoxin $\mathrm{M}_{1}$ removal from aqueous solutions by Flavobacterium aurantiacum. Mycopathologia et Mycologia Applicata, v.45, n.3-4, p.259-266, 1971.

LINE, J.E.; BRACKETT, R.E. Factors affecting aflatoxin $\mathrm{B}_{1}$ removal by Flavobacterium aurantiacum. Journal of Food Protection, v.58, n.1, p.91-94, 1995.

MAGAN, N.; OLSEN, M. Mycotoxins in food - Detection and Control. Boca Raton: CRC Press, 2006.

MISHRA, H.N.; DAS, C. A Review on biological control and metabolism of aflatoxin. Critical Reviews in Food Science and Nutrition, v.43, n.3, p.245-264, 2003.

MURPHY, P.A.; HENDRICH, S.; LANDGREN, C.; BRYANT, C.M. Food Mycotoxins: An Update. Journal of Food Science, v.71, n.5, p.51-65, 2006.

NIERMAN, W.C. et al. Mycotoxin Production and Prevention of Aflatoxin Contamination in Food and Feed. In: GOLDMAN, G.H.; OSMANI, S.A. The Aspergilli: Genomics, Medical Aspects, Biotechnology, and Research Methods. CRC Press, 2008. Cap. 27, p.457-472.

OATLEY, J.T.; RARICK, M.D.; JI, G.E.; LINZ, J.E. Binding of aflatoxin $B_{1}$ to bifidobacteria in vitro. Journal of Food Protection, v.63, n.8, p.1133-1136, 2000.

OLIVEIRA, C.A.F.; GERMANO, P.M.L. Aflatoxinas: conceitos sobre mecanismos de toxicidade e seu envolvimento na etiologia do câncer hepático celular. Revista de Saúde Pública, v.31, n.4, Ago. 1997. 
OLIVEIRA, C.A.F.; ROSMANINHO J.; ROSIM, R. Aflatoxin $\mathrm{M}_{1}$ and cyclopiazonic acid in fluid milk traded in São Paulo, Brazil. Food Additives and Contaminants, v.23, p.196-201, 2006.

OLIVEIRA, C.A.F.; FERRAZ, J.C.O. Occurrence of aflatoxin $\mathrm{M}_{1}$ in pasteurised, UHT milk and milk powder from goat origin. Food Control, 18: 375-8, 2007.

OLIVEIRA, C.A.F.; SEBASTIÃO, L.S.; FAGUNDES, H.; ROSIM, R.E.; FERNANDES, A.M. Aflatoxins and cyclopiazonic acid in feed and milk from dairy farms in São Paulo, Brazil. Food Additives and Contaminants, v.1, p.147-52, 2008.

OLUWAFEMI, F.; DA-SILVA, F.A. Removal of aflatoxins by viable and heat-killed Lactobacillus species isolated from fermented maize. Journal of Applied Biosciences, v.16, p.871-876, 2009.

ONILUDE, A.A.; FAGADE, O.E.; BELLO, M.M.; FADAHUNSI, I.F. Inhibition of aflatoxin-producing aspergilli by lactic acid bacteria isolates from indigenously fermented cereal gruels. African Journal of Biotechnology, v.4, n.12, p.1404-1408, 2005.

PARK, D.L.; LIANG, B. Perspectives on aflatoxin control for human food and animal feed. Trends in Food Science \& Technology, v.41, p.334-342, 1993.

PARK, D.L.; AYALA, C.E.; GUZMAN-PEREZ, S.E.; LOPEZ-GARCIA, R.; TRUJILLO, S. Microbial Toxins in Foods: Algal, Fungal, and Bacterial. In: HELFERICH, W.; WINTER, C.K. Food Toxicology. Boca Raton: CRC Press, 2000. Cap. 5.

PELTONEM, K.; EL-NEZAMI, H.; HASKARD, C.; AHOKAS, J.; SALMINEN, S. Aflatoxin $\mathrm{B}_{1}$ binding by dairy strains of lactic acid bacteria and bifidobacteria. Journal of Dairy Science, v.84, p.2152-2156, 2001.

PIERIDES, M.; EL-NEZAMI, H.; PELTONEM, K.; SALMINEM, S.; AHOKAS, J. Ability of dairy strains of lactic acid bacteria to bind aflatoxin $\mathrm{M}_{1}$ in a food model. Journal of Food Protection, v.63, n.5, p.645-650, 2000.

PRADO, G.; OLIVEIRA, M.S.; PEREIRA, M.L.; ABRANTES, F.M.; SANTOS, L.G.; VELOSO, T. Aflatoxin $M_{1}$ in samples of "Minas" cheese commercialized in the city of Belo Horizonte - Minas Gerais/Brazil. Ciência e Tecnologia de Alimentos, v.20, n.3, 2000. 
PRANDINI, A.; TANSINI, G.; SIGOLO, S.; FILIPPI, L.; LAPORTA, M.; PIVA, G. On the occurrence of aflatoxin $\mathrm{M}_{1}$ in milk and dairy products. Food and Chemical Toxicology, v.47, p.984-991, 2009.

RASIC, J.L.; SKRINJAR, M.; MARKOV, S. Decrease of aflatoxins $B_{1}$ in yoghurt and acidified milks. Mycopathologia, v.113, p.117-119, 1991.

REVANKAR, S.G. Clinical implications of mycotoxins and stachybotrys. American Journal of the Medical Sciences, v.325, p.262-274, 2003.

SALMINEN, S.; OUWEHAND, A.C.; VON WRIGHT, A.; DALY, C. Future Aspects of Research and Product Development of Lactic Acid Bacteria. In: SALMINEN, S.; VON WRIGHT, A.; OUWEHAND, A.C. Lactic Acid Bacteria: Microbiological and Functional Aspects. 3.ed. New York: Marcel Dekker, Inc., 2004. Cap. 22.

SARIMEHMETOGLU, B.; KÜPLÜLÜ, Ö. Binding ability of aflatoxin $\mathrm{M}_{1}$ to yoghurt bacteria. Ankara Üniv Vet Fak Derg, v.51, p.195-198, 2004.

SAS Institute. SAS ${ }^{\circledR}$ User's Guide: Statistics. SAS Institute Inc., Cary, NC., 1992.

SCOTT, P.M.. Natural poisons. In: Helrich, K., editors. Official methods of analysis of the Association of Official Analytical Chemists. 15.ed. Arlington: Association of Official Analytical Chemists (AOAC); 1990. p.1184-213.

SEKIYAMA, B.L.; FERRARI, G.; MACHINSKI JUNIOR, M. Processos de descontaminação de rações contendo micotoxinas. Revista Analytica, n.26, p.64-67, 2007.

SHAHIN, A.A.M. Removal of aflatoxin $\mathrm{B}_{1}$ from contaminated liquid media by dairy lactic acid bacteria. International Journal of Agriculture \& Biology, v.9, n.1, p.71-75, 2007.

SHETTY, P.H.; JESPERSEN, L. Saccharomyces cerevisiae and lactic acid bacteria as potential mycotoxin decontaminating agents. Trends in Food Science \& Technology, v.17,p.48-55, 2006.

SHUNDO, L.; SABINO, M. Determinação de aflatoxina $M_{1}$ em leite por coluna de imunoafinidade CCD/CLAE. Brazilian Journal of Microbiology, v.37, n.2, abr./jun. 2006. 
SHUNDO, L.; NAVAS, S.A.; LAMARDO, L.C.A.; RUVIERI, V.; SABINO, M. Estimate of aflatoxin $\mathrm{M}_{1}$ exposure in milk and occurrence in Brazil. Food Control, v.20, p.655657, 2009.

SYBESMA, W.F.; HUGENHOLTZ, J. Food fermentation by lactic acid bacteria for the prevention of cardiovascular disease. In: ARNOLDI, A. Functional Foods, Cardiovascular Disease and Diabetes. CRC Press, 2004. Cap. 21.

VAN EGMOND, H.P.; JONKER, M.A. Worldwide regulations on aflatoxins - The situation in 2002. Toxin Reviews, v.23, p.273-293, 2004.

WALSTRA, P.; WOUTERS, J.T.M.; GEURTS, T.J. Dairy Science and Technology. 2.ed. Boca Raton: CRC Press, 2006.

WU, Q.; JEZKOVA, A.; YUAN, Z.; PAVLIKOVA, L.; DOHNAL, V.; KUCA, K. Biological degradation of aflatoxins. Drug Metabolism Reviews, v.41, n.1, p.1-7, 2009.

ZINEDINE, A.; FAID, M.; BENLEMLIH, M. In Vitro Reduction of Aflatoxin $B_{1}$ by Strains of Lactic Acid Bacteria Isolated from Moroccan Sourdough Bread. International Journal of Agriculture \& Biology, v.7, n.1, p.67-70, 2005. 